ELECTRIC POWER RESEARCH INSTITUTE

\title{
ENVIRONMENTAL CONTROL TECHNOLOGY CENTER
}

REPORT TO THE STEERING COMMITTEE

May 1995 Monthly DE FGD29 $93 P C 93256$
Approved Final Technical,Report

US/DOE Patent Clearance is not Required

Prior to the Publication of this Document

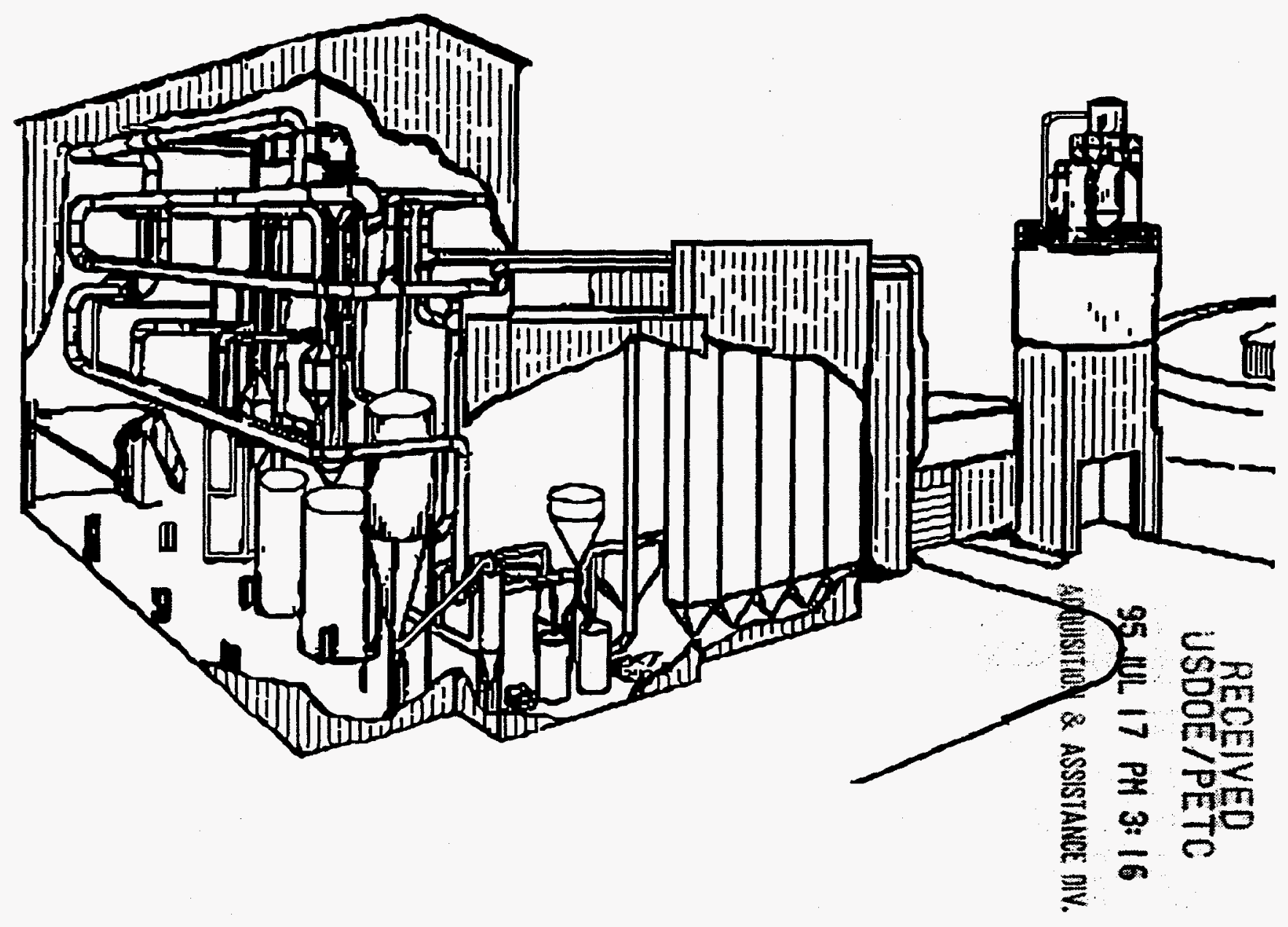

PROCESSED FROM BEST AVAILABLE COPY 
For further information on:

Facility Operations and Miscellaneous ECTC inquires;

contact - Gary Andes (716) 795-3397

Wet FGD/Toxics Testing;

contact - Rob Moser (415) 855-2277

Spray Drying/Dry FGD/Duct Injection technologies;

contact - Richard Rhudy (415) 855-2421

\section{DISCLAIMER}

This report was prepared as an account of work sponsored by an agency of the United States Ther Government nor any agency thereof, nor any of their employees, makes any warranty, express or implied, or assumes any legal liability or responsibility for the accuracy, completeness, or usefulness of any information, apparatus, product, or process disclosed, or represents that its use would not infringe privately owned rights. Referprocess disclosed, ence herein to any secommanufacturer, or orited States Government or any agency thereof. The views mendation, or favoring by the United State United States Government or any agency thereof.

This monthly report is a compilation of monthly progress reports by EPRI contractors (Radian Corporation, Gilbert/Commonwealth) connected with the Environmental Control Technology Center (ECTC). This report is intended to provide timely information to the ECTC co-sponsoring organizations. All data and results should be considered preliminary. Neither EPRI, members of EPRI, Radian, Gilbert/Commonwealth, nor any person acting on behalf of any of them: (a) makes any warranty, express or implied, with respect to the use of any information, apparatus, method, or process disclosed in this report or that any such use may not infringe privately owned rights; or (b) assumes any liabilities with respect to the use of, or for damages resulting from the use of any information, apparatus, method, or process disclosed in this report. 


\section{TABLE OF CONTENTS}

EXECUTIVE SUMMARY..................................................................................

SECTION I FACILITY STATUS

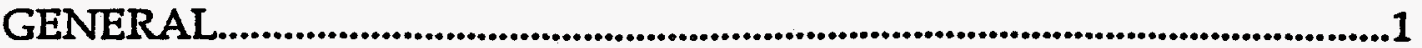

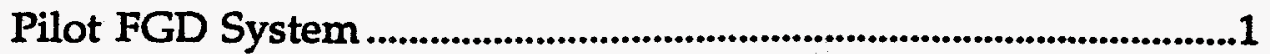

Carbon Injection System ........................................................................2

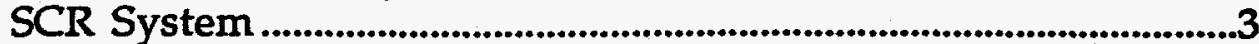

Auxiliary Systems.............................................................................................

Financial Report...............................................................................................4

SECTION II PILOT AND MINI-PILOT TEST ACTIVITY..........................7

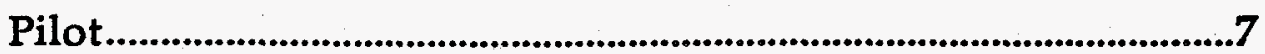

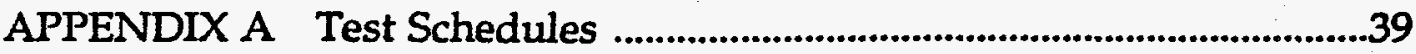

APPENDIX B Pilot and Mini-Pilot data ...............................................42

ECTC COSPONSORS DISTRIBUTION ….........................................................47 


\section{LIST OF FIGURES}

\section{Eigure}

i. 1994 Operation \& Maintenance Costs.......................................................5

1. Process Flow Diagram for Carbon Injection Testing - ESP..............20

2. Process Flow Diagram for Carbon Injection Testing - PJFF ............21

3. Results from PJFF Tests...........................................................................22

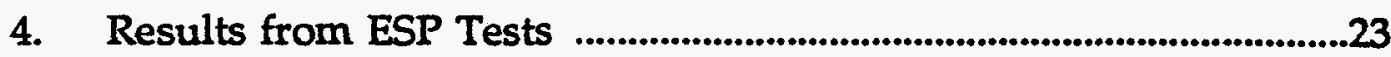

5. Process Flow Diagram for TER and LDG Tests.................................24

6. Method 29 Sampling Train..................................................................................25

7. Mercury Spiking Apparatus .......................................................................26

Table

\section{LIST OF TABLES}

i. Monthly Operating Costs By Task..........................................................4

1. May Operating Summary.....................................................................27

2. Carbon Injection Test Conditions and Results.....................................32

3. Trace Element Removal Impinger Test Conditions..........................33

4. Comparison between Method 29 and Method 29*...........................34

5. Intratrain Spiking Results before First Impinger..................................35

6. Intratrain Spiking Results after Second Impinger...............................36

7. Summary of LDG Test Conditions and Results ..................................37 


\section{LIST OF COMMON ABBREVIATIONS}

A-S-H. Allen Sherman Hoff

BES Bulk Entrainment Separator

CRG Clean Raw Gas

CLS Clear Liquor Scrubbing

DBA Di-Basic Acid

DRG Dirty Raw Gas

ECTC Environmental Control Technology Center

EDR Electrodialysis Reversal Membrane Unit

ESP. Electrostatic Precipator

FF Fabric Filter

FGD Flue Gas Desulfurization

FLRT First Loop Reaction Tank

FRP Fiberglass Reinforced Plastic

G/C. Gilbert/Commonwealth Inc.

GEESI General Electric Environmental Services Inc.

HME Horizontal Mist Eliminator

HSSD. High Sulfur Spray Dryer

HYPAS ..Hybrid Pollution Abatement System

ID .Induced Draft

L/G ...Liquid to Gas Ratio, (gal/1000ft ${ }^{3}$ )

MFT Master Fuel Trip

MRT ..Main Reaction Tank

NTU Number of Transfer Units

NYSEG .New York State Gas \& Electric

$O \& M$ .Operations \& Maintenance

PJFF Pulse Jet Fabric Filter

RTD Resistance Temperature Detector

RWST Recycle Water Storage Tank

SCBA Scott Air Packs

SDA Spray Dry Absorber

UMIST Univ. of Manchester Inst. of Science \& Technology

VME .Vertical Mist Eliminator

VSD Variable Speed Drive

WDPF Westinghouse Distributed Process Control System 


\section{EXECUTIVE SUMMARY}

Operations and maintenance continued this month at the Electric Power Research Institute's Environmental Control Technology Center. Testing on the $4.0 \mathrm{MW}$ Pilot Wet FGD unit continued this month with the Carbon Injection (Mercury removal) test block and the Trace Element Removal (TER) tests. On the Cold-Side Selective Catalytic Reduction (SCR) unit, baseline performance testing continued this month as measurements were taken for NOx removal efficiency, residual ammonia slip, and $\mathrm{SO}_{3}$ generation across the new catalysts installed in the $\mathrm{SCR}$ reactor.

\section{Pilot Testing Highlights}

Three test programs were performed in May at EPRI's Environmental Control Technology Center (ECTC). Phase I of the 1995 Carbon Injection (C) test block was completed during the first two weeks of May, followed by the Trace Elements Removal (TER) test block. While completing impinger studies for the TER test block, the pilot system was configured to continue the Lime-DBA-Gypsum (LDG) testing that was started in April. The results for each test series are detailed in separate sections.

\section{CARBON INJECTION TESTS}

Phase I of the 1995 Carbon Injection Test Block (CT) was completed in May as part of EPRI's overall program for developing control technology options for trace element emissions. The overall objective of this test block is to evaluate mercury removal from utility flue gas streams by injecting activated carbon into the flue gas. Results from Phase I will be used to develop further test conditions to be investigated during Phase II (scheduled for July 1995).

\section{TRACE ELEMENT REMOVAL TESTS}

The Pilot Trace Elements Removal test block continued in May as part of EPRI's overall program to develop control technology options for trace element emissions. This experimental program investigates trace element removal efficiencies across wet flue gas desulfurization (FGD) systems. The 1995 six-month program will use the 4.0 MW wet FGD pilot unit at EPRI's Environmental Control Technology Center (ECTC).

\section{LIME-DBA-GYPSUM TESTS}

Results from the High-Calcium Lime with Additives (HCLA) test block, completed on EPRI's 0.4 MW mini-pilot FGD system in September 1993, indicated that a forced-oxidation lime slurry process with DBA was a potential retrofit alternative for existing $\mathrm{Mg}$-lime or Dual-alkali FGD systems. Based on these results, a six- 
week test block was started in March on EPRI's 4.0 MW pilot FGD system. Results from the 1995 Lime-DBA-Gypsum (LDG) tests showed that full oxidation can be achieved; however, the gypsum solids properties are not as good as typical limestone gypsum solids. Because of the encouraging results from the 1995 test block, further testing was performed using a magnesium-enhanced lime process in May. Three tests were completed that examined the effect of lime dispersion within the reaction tank, increased slurry weight percent, and use of a pre-mix tank on the gypsum dewatering properties. Results from these tests showed that although there was slight improvement in solids properties, gypsum quality may still be too poor for resale. 


\section{SECTION I FACILITY STATUS}

\section{GENERAL}

The NYSEG Kintigh Station provided flue gas to the Center $100 \%$ of the time during this performance period. As the Kintigh Station operated with a variety of coals, fluctuations in the Center's inlet $\mathrm{SO}_{2}$ concentrations were experienced.

Safety training for the month was conducted by the O\&M Superintendent and Shift Supervisors. "Confined Space" permitting, entry and work procedures were the topics of the month. Inspections of the ECTC Facility and safety equipment (SCR airpacks, fire extinguishers, etc.) were completed and recorded this month. All systems were found to be in good condition. By continuing to emphasize safe work habits at the Center, we have raised the total number of days without a lost time injury to 1091 as of $5 / 31 / 95$.

The monthly safety meeting with the NYSEG Kintigh Station was held on May 15 with both NYSEG and ECTC representatives to discuss shared states of responsibility, operations and future activities. The major topics of discussion this month were the $\mathrm{NH}_{3}$ alarm signal from the ECTC SCR unit into the NYSEG FGD control room, and an update of the plans for the ECTC June outage required for ductwork modifications for the next phase of High Velocity FGD testing.

\section{PILOT WET FGD SYSTEM}

The equivalent and actual availabilities for the ECTC 4.0 MW Pilot Wet FGD System testing this month were both $100 \%$ during this period.

The Trace Element Removal (TER) tests were resumed this month with tests TER-2 and TER-2A. These tests were conducted under similar conditions to the Lime Forced Oxidation with DBA addition (LDG) test block in April. For this month's testing, modifications were made to the reagent (lime/limestone) feed system to the Pilot FLRT tank to deliver reagent as close to the impeller as possible for better reagent distribution and solids properties. A pre-mix tank was also used later in the configuration for reagent dilution. The operational parameters for the Pilot Wet Scrubber during this test block included: gas flows of $11,000 \mathrm{scfm} ; 2000 \mathrm{ppm}$ inlet $\mathrm{SO}_{2}$; a recycle slurry flow of $400 \mathrm{gpm}$; varying oxidation air rates; reaction tank slurry solids concentrations of 25 and 30\%; reaction tank levels of $8 \mathrm{ft}$., and an absorber inlet temperature of $315^{\circ} \mathrm{F}$.

The following maintenance work was completed on the Pilot Wet Scrubber unit during this performance period:

- Repairs to the VME spool piece were completed. 
- The Munters VME was removed and the Koch VME sections were installed.

- The backdrive and main motors for the centrifuge were reconditioned and installed.

\section{CARBON INIECTION SYSTEM}

The equivalent and actual availabilities for the ECTC Carbon Injection (Mercury removal) test block this month were both $92 \%$ respectively during this period. The Carbon Injection System did not operate during the following periods:

- May 1 - 3 for 24 hours to inspect the PJFF bags and seal several tubesheet blanking plates.

- May 9 for 4 hours to configure the flue gas path with the ESP and to isolate the PJFF.

- May 11-12 for 24 hours to modify the flue gas path configuration with the ESP and to isolate the PJFF.

- May 20-21 for 5 hours due to a high temperature trip on the ESP booster fan.

Phase I of the 1995 Carbon Injection test block was completed this month with tests PJFF-1 through PJFF-5; test PJFF-2T; and test PJFF-3R. These tests utilized the SDA unit as an open vessel for gas residence time, the activated carbon screw feeder system, the PJFF for carbon/particulate removal, and the ESP booster fan. Additionally, tests ESP-1 through ESP-5 were completed during this test block. These tests also used the SDA, ESP booster fan, and the activated carbon screw feeder system; however, in these tests the ESP was utilized for carbon/particulate removal. The operational parameters for the PJFF/ESP test configurations during this period included: gas flows of 4270, 4500, 9700 and 10,200 scfm; $1600 \mathrm{ppm}$ inlet $\mathrm{SO}_{2}$ a lime feed rate of $0.25-0.65 \mathrm{gpm}$ at $5-10 \%$ solids (by weight); and carbon injection rates of $0.33-1.49 \mathrm{lb} . / \mathrm{hr}$. At the end of this test block, various carbon/lime blends were also injected into the system to determine their efficiency.

The following maintenance work was completed on the Carbon Injection system during this performance period:

- Several visalite tests were conducted on the PJFF to check for any bag leaks or gaps in the tubesheet.

- All leaks/holes around the PJFF tubesheet blanking plates and cage flanges were sealed. 


\section{COLD-SIDE SELECTIVE CATALYTIC REDUCTION SYSTEM (SCR)}

The equivalent and actual availabilities for the ECTC SCR System testing were both $100 \%$ during this period.

Catalyst performance testing continued this month on the SCR unit at baseline conditions. This month, measurements were taken for $\mathrm{NO}_{\mathrm{x}}$ removal efficiency, residual ammonia slip, and $\mathrm{SO}_{3}$ generation across the new catalysts installed in the SCR reactor. The operational parameters for the SCR unit during this testing included: a gas flow rate of $2000 \mathrm{scfm}$; catalyst inlet gas temperature of $650^{\circ} \mathrm{F}$; inlet $\mathrm{NH}_{3}$ pressures of $50 \mathrm{psi}$; and $\mathrm{NH}_{3} / \mathrm{NO}_{\text {x }}$ ratios of 0.7 to 1.0 .

The following maintenance work was completed on the SCR unit during this performance period:

- Scheduled maintenance was completed on the system equipment and instrumentation.

\section{MISCELLANEOUS}

The Paste Slaker and Ball Mill operations were normal this month during the preparation of Bellefonte lime and Beachville limestone. The slaked lime slurry prepared for ECTC operations this month was $25 \%$ solids at $190^{\circ} \mathrm{F}$, while the limestone grind prepared for ECTC operations was $95 \%$ passing 325 mesh screen.

In preparation for the next phase of High Velocity FGD Scrubbing (20 fps), the ECTC has scheduled a Facility outage $(6 / 12-6 / 19)$ to make the necessary duct modifications and system reconfigurations. This month, the selected construction contractor and the ECTC O\&M staff began the removal of duct insulation, the setup of scaffolding, and new ductwork fabrication. Additionally, the first of the three facility fan assemblies (the fabric filter fan) was disassembled as new fan wheels are to be installed in each fan and the fan motors are to be overhauled prior to service. 


\section{FINANCIAL REPORT}

The Financial Report for the four Operations and Maintenance contract tasks are summarized below for the month of May 1995, the year to date, and the contract total.

Task Definitions:

Task 100: Operations and Maintenance Labor

Task 200: Purchased Materials

Task 300: Engineering Support

Task 400: Training

Table i.

Monthly Operating Costs by Task

\begin{tabular}{|c|c|c|c|c|}
\hline & & May & Year to Date & Contract Total \\
\hline Task 100 & $\$$ & 98,021 & $\$ 519,764$ & $\$ 12,932,455$ \\
\hline Task 200 & $\$$ & 14,928 & \$ 127,215 & $\$ 7,412,857$ \\
\hline Task $200^{*}$ & $\$$ & 0 & $\$ 132,133$ & 132,133 \\
\hline Task 300 & $\$$ & 2,841 & $\$ 15,648$ & \$ $1,085,683$ \\
\hline Task 400 & & 2.279 & $\$ \quad 12.094$ & $\$ \quad 46,898$ \\
\hline TOTAL & $\$$ & 118,069 & $\$ 806,854$ & $\$ 21,610,026$ \\
\hline
\end{tabular}

Task Definitions:

Task 100: Operation \& Maintenance Labor

Task 200: Purchased Materials

Task 300: Engineering Support

Task 400: Training

Task 200*: Expenditures funded from third party testing revenues. 
The attached graph illustrates the budgeted and actual expenses for ECTC O\&M activities through May 1995.

Figure i.

1995 Operation \& Maintenance Costs

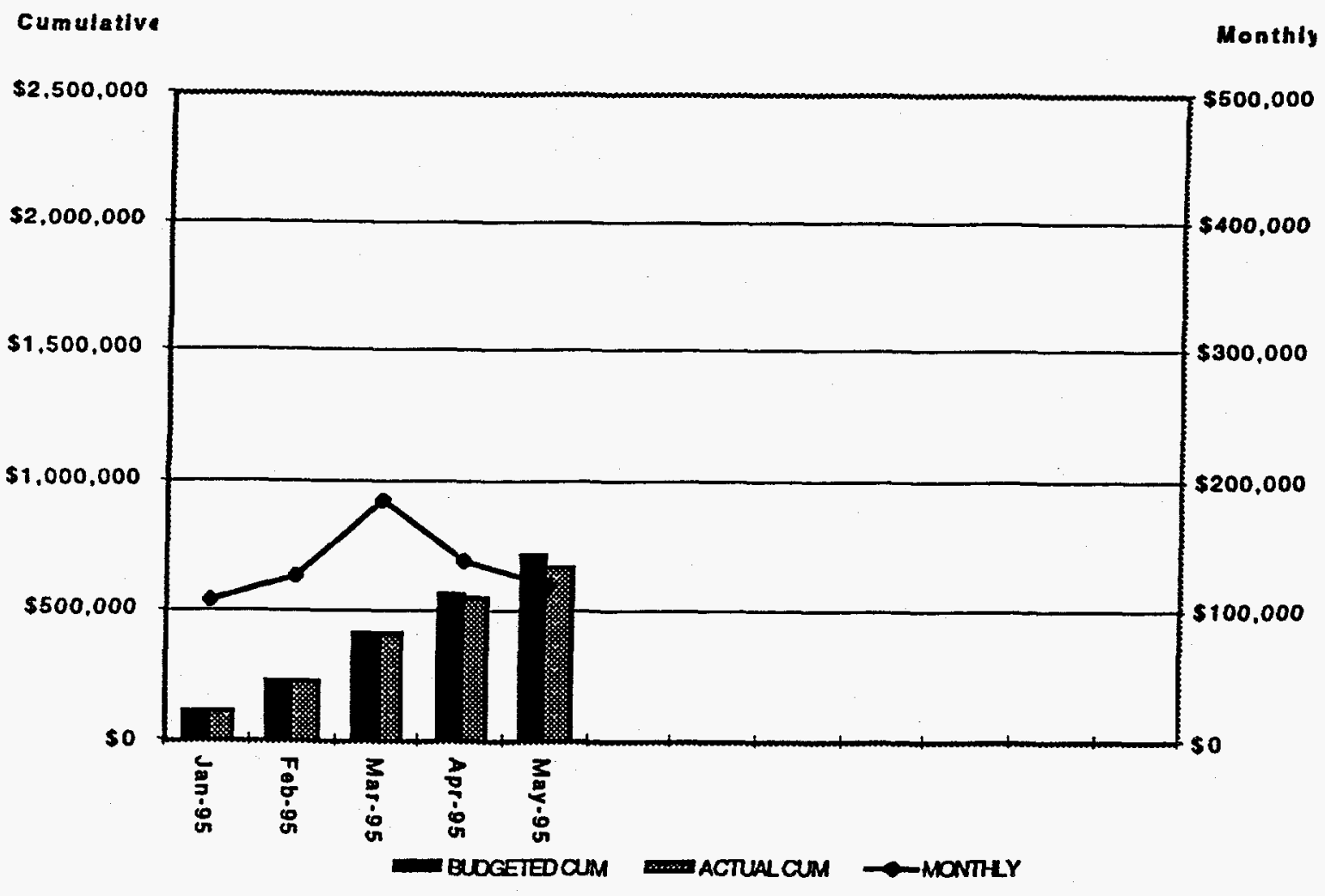




\section{SECTION II PILOT AND MINI-PILOT TEST ACTIVITY}

\section{PILOT}

\section{Overview}

Three test programs were performed in May at EPRI's Environmental Control Technology Center (ECTC). Phase I of the 1995 Carbon Injection (CI) test block was completed during the first two weeks of May, followed by the Trace Elements Removal (TER) test block. While completing impinger studies for the TER test block, the pilot system was configured to continue the Lime-DBA-Gypsum (LDG) testing that was started in April. The results for each test series are detailed in separate sections.

\section{CARBON INJECTION TESTS}

Phase I of the 1995 Carbon Injection Test Block (C) was completed in May as part of EPRI's overall program for developing control technology options for trace element emissions. The overall objective of this test block is to evaluate mercury removal from utility flue gas streams by injecting activated carbon into the flue gas. Results from Phase I will be used to develop further test conditions to be investigated during Phase II (scheduled for July 1995).

\section{Background}

Previous activated carbon injection tests were performed in 1994 using the 4.0 MW pilot spray dryer unit and the pilot particulate removal devices at the ECTC. Three different process configurations were used to evaluate the effect of carbon injection on mercury removal across the particulate removal devices. These configurations consisted of injecting carbon upstream of the pulse jet fabric filter (PJFF), upstream of the electrostatic precipitator (ESP), and between the ESP and PJFF. Other test variables included the carbon injection rate and the flue gas temperature. The flue gas temperature was controlled by injecting a dilute limestone slurry and additional temperature control water into the spray dryer vessel upstream of the particulate removal device.

The 1994 tests resulted in the following conclusions:

- Flue gas cooling by humidification increased mercury removal when using each of the three process configurations;

- The mercury removal efficiency was higher using a PJFF compared with an ESP;

- Under certain operating conditions, very high mercury removal efficiencies were achieved by using an ESP and PJFF in series. 


\section{Test Block Objectives}

Based on the 1994 carbon injection results, 1995 Phase I carbon injection test conditions were developed to further investigate the effects of carbon injection rate, flue gas temperature, and gas residence time on mercury removal. Using both the pilot ESP and PJFF for particulate control, the specific objectives of Phase I were to:

- Determine the process conditions required to achieve greater than $90 \%$ mercury removal;

- Provide data to support the development of a mathematical model that will predict mercury removal efficiencies for the carbon injection processes.

The test variables were flue gas temperature and duct residence time during the ESP tests, and flue gas temperature and carbon injection rate during the PJFF tests.

\section{Summary of Operations}

A detailed summary of operations for May is presented in Table 1. During Phase I of the carbon injection test block, thirteen tests were completed using two different process configurations. Figures 1 and 2 show simplified process flow diagrams for these two configurations. Flue gas entering the spray dryer absorber vessel (SDA) was heated to about $350^{\circ} \mathrm{F}$. A small amount of lime slurry (rather than limestone as in 1994) was spray dried in the SDA to minimize corrosion from flue gas sulfuric acid condensation. Temperature control water was also injected to control the particulate control device inlet gas temperature at the desired value. After exiting the SDA at the desired gas temperature, the flue gas passed through either the ESP or PJFF.

Dry activated carbon (Darco FGD, marketed by American Norit) was pneumatically injected into the duct downstream of the SDA and upstream of the particulate removal device. The carbon injection system consisted of a small screw feeder with a self-contained hopper and a solids injection nozzle. The motor speed of the feeder was set to give the desired solids injection rate. The actual injection rate was determined by measuring the amount of carbon discharged from the feeder in a timed interval. Carbon from the feeder fell into a plastic funnel that was connected to a solids injection nozzle within the duct. Because the duct was under negative pressure, the carbon was entrained into ambient air aspirated through the injection nozzle/funnel assembly. The nozzle was positioned in the center of the duct and aligned cocurrently with flue gas flow.

To determine the mercury removal across the particulate removal device at each test condition, simultaneous gas samples were collected at the SDA outlet (upstream of the carbon injection port) and at the outlet of the particulate control device. Gas samples were collected using a modification of EPA Draft Method 29. Primary modifications included non-isokinetic gas sampling at a single-point within the 
duct (i.e., the duct was not traversed) and removal of the water knockout impingers before the peroxide impingers. The $\mathrm{H}_{2} \mathrm{O}_{2} / \mathrm{HNO}_{3}$ impingers were combined and analyzed separately from the combined $\mathrm{KMnO}_{4} / \mathrm{H}_{2} \mathrm{SO}_{4}$ impingers. Probe and nozzle rinses after each gas sampling test were combined and analyzed separately from the particulate filter.

One test condition was completed each day with three gas samples collected at each gas sampling location. The carbon injection rate and other process conditions were established at least 12 hours before gas sampling began. During the evening and midnight shifts, operators checked the carbon flow rate every 4 hours and made adjustments to keep the flow within $\pm 20 \%$ of the set point. The carbon injection rate was also measured before each gas sampling run. Fly ash samples were collected at the end of each test from the ESP or PJFF and the SDA cone. Activated carbon samples were also collected.

\section{Summary of Carbon Injection Results}

As mentioned earlier, two configurations were used during Phase $I$ of the CI test series. Carbon was initially injected upstream of the PJFF and then upstream of the ESP. Table 2 summarizes the test conditions and results using both configurations, and these results are discussed separately below.

\section{Pulse Jet Fabric Filter Results}

Eight PJFF tests were conducted during Phase I. Test variables included the PJFF inlet gas temperature and carbon injection ratio (mass of carbon injected to mass of inlet mercury). During two tests (PJFF-4 and PJFF-5), two parts dry lime were mixed with one part carbon and injected into the duct. For tests conducted at $225^{\circ} \mathrm{F}$ and $275^{\circ} \mathrm{F}$, lime slurry was continuously sprayed into the spray dryer upstream of the inlet sampling location to control the flue gas temperature. No slurry was sprayed during the $325^{\circ} \mathrm{F}$ test.

Carbon injection ratios of 3000 and 8000 were to be tested during the PJFF tests. The carbon injection rate was initially calculated by assuming that the flue gas vaporphase mercury concentration was equal to the average value obtained in 1994. However, this assumption proved to be incorrect. During the 1994 PJFF tests, the average vapor-phase inlet mercury concentration was $11.1 \mu \mathrm{g} / \mathrm{Nm}^{3}$ compared with $5.3 \mu \mathrm{g} / \mathrm{Nm}^{3}$ in 1995. This change resulted in much higher injection ratios at each of the PJFF operating conditions. Two test conditions were repeated after adjusting the injection rate for the lower mercury concentration (tests PJFF-2RR and -3R).

In addition to a decrease in the vapor-phase mercury concentrations during the 1995 tests, the solid-phase mercury concentrations were much higher than those observed in 1994 (approximately $1.5 \mu \mathrm{g} / \mathrm{Nm}^{3}$ vs. $0.04 \mu \mathrm{g} / \mathrm{Nm}^{3}$ ). Although this change did not affect the carbon injection ratio, this change may indicate that the inlet vapor-phase mercury concentrations were biased low during some tests. Some 
of the 1995 data suggests that lime may have reacted with the inlet vapor-phase mercury to result in the high solid concentrations. If this occurred, the apparent vapor-phase mercury removal would be incorrect because of a biased inlet vaporphase concentration. Because of this potential problem, total mercury removals obtained in 1995 were compared with the vapor-phase mercury removals in 1994. Because the solid concentrations were so low in 1994, the vapor-phase removals were essentially equal to the total removals.

Figure 3 compares the total mercury removal across the PJFF in 1995 to that observed in 1994 . At a flue gas temperature of $225^{\circ} \mathrm{F}$, mercury removal in 1995 was lower than in 1994 at a given carbon injection ratio. The 1995 data at $225^{\circ} \mathrm{F}$ also suggest that operating at carbon injection ratios higher than about 5000 is not justified since no increase in removal was observed. Increasing the flue gas temperature to $275^{\circ} \mathrm{F}$ in 1995 increased mercury removal. In 1994, both the ESP and PJFF tests indicated that mercury removal decreased at a given carbon injection ratio as the flue gas temperature increased. These discrepancies between the 1995 and 1994 PJFF results have not been resolved.

Unlike the $225^{\circ} \mathrm{F}$ data, data collected at $325^{\circ} \mathrm{F}$ appear to indicate that mercury removal was much higher in 1995 than in 1994; however, the test conditions between 1994 and 1995 were not identical. During 1995, carbon was injected as a mixture of carbon and lime; therefore, the lime may explain the improved mercury removal. In addition, the $325^{\circ} \mathrm{F}$ data from 1994 are difficult to interpret. The mercury removal with no carbon injection was $-40 \%$; therefore, the removal obtained at an injection ratio of 10,000 may be biased low due to the negative baseline removal.

\section{Electrostatic Precipitator Results}

Five ESP tests were conducted during Phase I. During these tests, the effect of gas temperature, gas residence time, and carbon injection rate on mercury removal was investigated. During test ESP-5, two parts dry lime were mixed with one part carbon and injected into the duct. Lime slurry was continuously sprayed into the spray dryer upstream of the inlet sampling location.

During the 1995 ESP tests, the vapor-phase mercury removal was negative at three test conditions (see Table 2). These removals are attributed to unreasonably low inlet mercury concentrations. These low inlet concentrations may be related to the injection of lime. As explained above, the solid mercury concentrations were much higher than previously measured, and these higher concentrations may be the result of mercury removal by the injected lime. Although this may have occurred, the total mercury concentrations (solid plus vapor) also appear to be unreasonably low; therefore, some of the ESP test results are suspect.

Figure 4 compares the total mercury removal across the ESP in 1995 to the vaporphase removal in 1994 . The ESP results indicate that at $225^{\circ} \mathrm{F}$, the mercury removal 
in 1995 was consistent with that in 1994 . The 1995 data collected at $275^{\circ} \mathrm{F}$ indicate lower removal than at $225^{\circ} \mathrm{F}$ which is the expected effect of temperature based on the 1994 results. However, the vapor-phase mercury removal during the $275^{\circ} \mathrm{F}$ test was negative, and therefore this test result is suspect.

At $275^{\circ} \mathrm{F}$, the carbon residence time in the flue gas duct was increased; and in a separate test, two parts lime were injected with one part carbon. Increasing the residence time appears to improve mercury removal. Injecting a mixture of lime and carbon appears to decrease removal. However, these results are also suspect given the problems with negative vapor-phase removals discussed above. During Phase II, some of these test conditions will be repeated.

\section{TRACE ELEMENT REMOVAL TESTS}

The Pilot Trace Elements Removal test block continued in May as part of EPRI's overall program to develop control technology options for trace element emissions. This experimental program investigates trace element removal efficiencies across wet flue gas desulfurization (FGD) systems. The 1995 six-month program will use the 4.0 MW wet FGD pilot unit at EPRI's Environmental Control Technology Center (ECTC).

\section{Background}

Wet FGD systems have the ability to remove solid-phase and vapor-phase trace elements that are present in flue gas streams. Because only a limited amount of test data are available to quantify trace element removal efficiencies across full-scale FGD systems, additional research is needed to better understand the removal mechanisms which may aid in the development of processes to increase the trace element removal efficiencies. Several test programs investigating trace element removal have been conducted. The most important results from full-scale and pilot-scale testing for trace element control by wet FGD systems are:

- Mercury is the primary vapor-phase trace element of interest to coal-fired power plants. Investigations of mercury removal from flue gas are complicated by the low flue gas concentrations (typically less than $1 \mathrm{ppbv}$ in utility flue gases) and because flue gas mercury can exist in different forms. The collected data to date show that the chemical form of the mercury can greatly affect the removal efficiency. Mercuric chloride is effectively removed by FGD systems, while elemental mercury is not. The challenge of obtaining high elemental mercury removal is the goal of future testing using wet FGD technology. 
- Mercury removal data collected at the ECTC and elsewhere are difficult to interpret because the currently available mercury speciation methods, especially when used at the FGD inlet location, do not result in successful speciation under all conditions.

- Solid-phase trace element removal can be approximated by the bulk particulate removal efficiency for the FGD system as long as the mass of condensed sulfuric acid and scrubber carryover are considered.

- Measured bulk particulate removal efficiencies across full-scale FGD systems are generally greater than $50 \%$ and are usually greater than predicted efficiencies based on theory. These higher-than-predicted removal efficiencies may be a result of an electrical charge on the inlet particles that causes an attraction to the slurry droplets, thereby improving particulate removal efficiency for the scrubber.

Given the difficulties in measuring mercury removal efficiencies relative to other trace element removal efficiencies, most of the ECTC testing has examined mercury removal across FGD systems.

Test Block Objectives

The 1995 Trace Elements Removal (TER) test block will focus on up to five research areas, depending on experimental results. These areas are:

- Mercury speciation methods;

- Effect of FGD system operating variables on mercury removal;

- Novel methods for elemental mercury control;

- Catalytic methods for converting elemental mercury to oxidized mercury; and

- Electrostatic charging of particulate material in the FGD inlet flue gas stream.

Testing in May focused on mercury speciation methods. The overall objective of this testing is to investigate the mercury speciation abilities of EPA Method 29 and to test methods of improvement if necessary. This overall objective will be satisfied by:

- Spiking element mercury $\left(\mathrm{Hg}^{0}\right)$ into the gas sampling train (intratrain spiking) to determine the percent spike recovery in the various impinger solutions;

- Spiking the inlet flue gas with $\mathrm{Hg}^{0}$ and $\mathrm{HgCl}^{2}$ to determine the percent spike recovery in the various impinger solutions; and

- Using novel impinger solutions to investigate the effect of these solutions on speciation capabilities. 


\section{Summary of Operations}

A detailed summary of operations for May is presented in Table 1. A simplified process flow diagram for the pilot unit, as configured for the trace element testing, is shown in Figure 5. TER testing in May evaluated the ability of EPA Method 29 and a modified method (Method 29*) to differentiate between oxidized mercury ( $\mathrm{HgCl}^{2}$ ) and elemental mercury $\left(\mathrm{Hg}^{\circ}\right)$ in the flue gas. Method 29, as shown in Figure 6, includes two impingers containing a peroxide/nitric acid solution (peroxide impingers) followed by two impingers containing a permanganate/sulfuric acid solution (permanganate impingers). Method $29^{*}$ is identical to Method 29 except two additional peroxide impingers are used upstream of the permanganate impingers. Method 29* can be further modified to include different solutions in the first two impingers, followed by the peroxide and permanganate impingers.

The analytical procedures used to recover the impinger samples from Method 29 and 29* are slightly different. For Method 29 trains, the two peroxide impingers are combined and the two permanganate impingers are combined. Flow injection cold vapor atomic absorption spectrometry (FI-CVAAS) is then used to analyze the combined solutions separately for mercury. For Method 29* trains, each of the peroxide impingers (four total) are analyzed individually and the permanganate impingers are combined. Mercury is measured using the same analytical method.

The speciation evaluation consisted of collecting Method 29* trains while spiking elemental mercury directly into the gas sampling train (intratrain spiking). The mercury was added to the train either before the first impinger or after the second impinger. The elemental mercury was spiked into the sampling trains using the system shown in Figure 7. This spiking system was developed because the previous method may have resulted in mercury condensation before entering the impinger train, thus, resulting in low spike recoveries. For the new system, a vessel was fabricated to contain approximately 1 liter of vapor and 5 lbs. of liquid mercury while maximizing the liquid mercury surface area. The vessel was placed in a water bath to maintain a constant temperature. A nitrogen stream, controlled by a rotameter, was used to carry the mercury laden vapor into the gas sampling train. Because the nitrogen is saturated with mercury at a known temperature and flow rate, the theoretical amount of mercury added to the sampling train can be calculated.

During the intratrain spiking tests, gas was sampled from either the atmosphere (ambient air), the wet scrubber inlet location, or the wet scrubber outlet location. While collecting each gas sample with mercury spiking, a simultaneous gas sample was collected in which no mercury was added (a blank). The amount of spiked mercury recovered in each impinger could then be determined by subtracting the amount of mercury in each impinger from the blank train from the amount of mercury in each impinger from the spiked train. If Method 29* successfully speciates mercury, $100 \%$ of the elemental mercury spike should be recovered in the permanganate impingers. 


\section{Summary of TER Results}

In May, several intratrain mercury spiking tests were conducted to evaluate the speciation capabilities of Method 29* (indirectly Method 29). Before conducting these tests, Method 29 and 29* were compared to verify that the same total mercury concentration was obtained and that similar speciation results were obtained with Method 29. Table 3 summarizes the impinger test conditions conducted in May. Mercury analytical data for all of the TER tests are appended to this report.

\section{Comparison of Method 29 and Method 29*}

Method 29 and Method 29* were compared in April to verify that both methods result in the same total mercury content in the flue gas. During this test, flue gas samples were collected at the clean raw gas (CRG) header (wet scrubber inlet upstream of mercury spiking) while spiking no elemental mercury into the flue gas (T1-NX): In May, this test was repeated except elemental mercury was spiked into the flue gas, and the gas was sampled at the wet scrubber inlet location (T7-EY). Table 4 summarizes the results from these two tests.

The data in Table 4 indicate that the two methods result in the same total mercury concentration both with and without mercury spiking in the flue gas. However, the amount of mercury captured by the permanganate impingers differs between the two methods. This difference is subtle with no mercury spiking but obvious with mercury spiking. While theoretically spiking $11.7 \mu \mathrm{g} / \mathrm{Nm}^{3}$ into the flue gas, Method 29 results indicate that $33 \%$ of the inlet flue gas mercury was captured in the permanganate impingers compared with only $17 \%$ for Method $29^{*}$. Based on the theoretical amount of mercury spiked during this test, the mercury recovery in these impingers should have been at least $65 \%$ if the sampling methods correctly speciate mercury. Results from these tests indicate that either elemental mercury is captured in the peroxide impingers or that some of the elemental mercury is converted to an "alternate form" which is efficiently removed by the peroxide impingers. These data are in agreement with the data gathered last year.

\section{Intratrain Spiking Before Impinger 1 Using Method 29*}

Table 5 summarizes the test results for intratrain spiking tests with the mercury injected before the first impinger of Method 29*. Intratrain spiking was done while collecting ambient air, wet scrubber inlet gas, and wet scrubber outlet gas. The percent of the spiked mercury recovered in each impinger is shown. If Method 29* speciates correctly, $100 \%$ of the mercury spike should be recovered in the permanganate impingers ( 5 and 6 ). Table 5 results are based on the average of three samples.

Mercury was spiked into the gas sampling train while collecting ambient air to determine if a significant amount of elemental mercury is collected in the peroxide impingers with no flue gas present. The data indicate that $98 \%$ of the mercury spike 
was captured in the permanganate solution. Therefore, essentially no elemental mercury is removed by the peroxide impingers in the absence of flue gas.

Spiking mercury into the sampling train while collecting flue gas at the wet scrubber inlet resulted in only $38 \%$ capture of the elemental mercury spike by the permanganate impingers. These results indicate that in the presence of flue gas either Method 29* does not accurately speciate elemental mercury from other forms of mercury or that the "alternate form" of mercury mentioned above is formed instantaneously in clean raw flue gas streams. This "alternate form" could be some type of complex between mercury and another flue gas component. These data are in agreement with data gathered last year.

At the wet scrubber outlet, $83 \%$ of the elemental mercury spike was captured in the permanganate impingers. Previous data indicated that $100 \%$ of the elemental mercury spike was captured by the permanganate impingers at the outlet. Although some of the elemental mercury spike was recovered in the peroxide impingers at the outlet location, a significantly smaller percentage was captured in these impingers compared with the capture at the inlet. During the intratrain spiking tests, the outlet gas $\mathrm{SO}^{2}$ concentration was approximately 150-250 ppmv compared with $2000 \mathrm{ppm}$ at the inlet. Similarly, the outlet $\mathrm{HCl}$ concentration was essentially zero compared with $40-50 \mathrm{ppm}$ at the inlet. These data indicate that the flue gas $\mathrm{SO}_{2}$ and/or $\mathrm{HCl}$ concentration may affect either the capture of elemental mercury in the peroxide impingers or the concentration of the "alternate form" of mercury.

\section{Intratrain Spiking After Impinger 2 Using Method 29*}

Since the capture of the elemental spike appears to correlate to the flue gas composition, elemental mercury spiking after the first set of peroxide impingers was tested. Essentially all of the flue gas $\mathrm{SO}_{2}$ and $\mathrm{HCl}$ are removed in the first two peroxide impingers; therefore, any effect these components have on mercury speciation should be removed by injecting mercury after the second impinger. Table 6 summarizes these results.

Results from spiking the mercury after the second impinger are similar to the results from spiking mercury before the first impinger. At the scrubber inlet, only $60 \%$ of the elemental mercury spike was captured by the permanganate solution while $92 \%$ was captured at the outlet location. While more of the spike was collected in the permanganate impingers at the outlet, the fraction collected across the peroxide impingers is similar whether the spike is added upstream of the first or the third impinger. These similar results were surprising since mercury injection occurred after $\mathrm{SO}_{2}$ and $\mathrm{HCl}$ had been removed from the gas stream by the first two peroxide impingers. The flue gas composition at the point of mercury injection should have been very similar at both the inlet and outlet locations; therefore, the difference in spike capture between the two locations was especially surprising. An explanation for these results is still being explored. 


\section{LIME-DBA-GYPSUM TESTS}

Results from the High-Calcium Lime with Additives (HCLA) test block, completed on EPRI's 0.4 MW mini-pilot FGD system in September 1993, indicated that a forced-oxidation lime slurry process with DBA was a potential retrofit alternative for existing Mg-lime or Dual-alkali FGD systems. Based on these results, a sixweek test block was started in March on EPRI's 4.0 MW pilot FGD system. Results from the 1995 Lime-DBA-Gypsum (LDG) tests showed that full oxidation can be achieved; however, the gypsum solids properties are not as good as typical limestone gypsum solids. Because of the encouraging results from the 1995 test block, further testing was performed using a magnesium-enhanced lime process in May. Three tests were completed that examined the effect of lime dispersion within the reaction tank, increased slurry weight percent, and use of a pre-mix tank on the gypsum dewatering properties. Results from these tests showed that although there was slight improvement in solids properties, gypsum quality may still be too poor for resale.

\section{Test Block Objectives}

The overall objective of the LDG test program is to evaluate the technical and economic feasibility of converting existing Mg-lime and dual-alkali FGD systems to slurry operation with DBA and forced oxidation to produce gypsum. The specific test objective for the LDG test program in May was to evaluate the effect of several process conditions on the solids properties. The process parameters examined in May included:

- Increased slurry solids concentration and reaction tank solids residence time, and

- Rapid lime reagent dispersion using a pre-mix tank and a new feed location.

The May tests investigated the effect reaction tank and chemistry modifications on gypsum solids properties. In addition, the test results should provide data to more accurately project both the capital and operating costs associated with conversion to this process.

\section{Summary of Operations}

A detailed summary of operations for May is presented in Table 1. The month's testing was a continuation of the test block started in March 1995. Bell Mine highcalcium chemical pebble lime obtained from the Bellefonte Lime Company was used during these tests. This lime contains about 1.0\% MgO. The LDG tests were run simultaneously with the Trace Elements Removal tests. Figure 5 showed a simplified process flow diagram for the pilot unit. A 38\%-open tray was used in the absorber during all tests to better simulate full-scale, gas-liquid contact area. The uppermost spray nozzles (header \#1) were used to introduce slurry into the absorber. 


\section{Summary of LDG Results}

The LDG tests were run in parallel with the Trace Element Removal test block. Complete analytical data tables and process data summary reports for all tests completed in May are appended to this report.

LDG testing in May indicated that:

- Feeding the reagent to the reaction tank at a location of high mixing slightly improved solids properties;

- Increasing reaction tank solids concentration increased the form filtration rate but not necessarily the filter leaf cake concentration; and

- Use of a reagent pre-mix tank improved solids properties.

Significant results for the LDG tests completed to date have been summarized in Table 7. Test ID's will no longer include the "LDG" prefix while running simultaneously with the Trace Elements Removal test block. Instead, each test will be denoted with at " $\mathrm{T}$ " prefix.

\section{Effect of Lime Dispersion within the Reaction Tank}

To increase the dispersion rate of lime within the reaction tank and promote a more uniform concentration in the reaction tank, the reaction tank was modified to introduce the lime reagent in the center of the tank at the impellers. Theoretically, better dispersement of the lime should reduce local gypsum relative saturations and result in larger gypsum particles. A 1-inch stainless steel pipe was attached to the pilot first loop reaction tank that entered the tank at an approximate 7-foot elevation and sloped at a $45^{\circ}$ angle to the impeller shaft. The discharge was positioned approximately 2 feet above the lower impeller and 4 feet below the upper impeller.

The tests run after the reaction tank modification had greater reaction tank solids concentration with greater solids residence times than previously tested (6.2 hours SRT for T3 and 17.5 SRT hours for test T4). These latest tests showed considerable improvement in some solids properties. The filter cake weight percent increased from $79 w t \%$ in test T3 (formerly LDG-15) to $84 \mathrm{wt} \%$ in test T4, and the thickener unit area decreased from 2.3 to $1.3 \mathrm{ft}^{2} / \mathrm{tpd}$, respectively. Although these solids properties improved, the form filtration rate dropped somewhat from $2557 \mathrm{lb} . / \mathrm{hrft}^{2}$ in $\mathrm{T} 3$ to $1557 \mathrm{lb} . / \mathrm{hrft}^{2}$ in $\mathrm{T} 4$. However, the form time for these high filtration rates can be extremely fast causing a greater chance for error. Overall, it appears that moving the feed location improved the solids properties of the gypsum somewhat; however, this effect cannot be completely separated from the effect of a longer solids residence time and a higher reaction tank solids concentration. 


\section{Effect of Higher Solids Concentration}

In test $\mathrm{T} 5$, the solids concentration in the reaction tank was increased slightly from 27 to $31 \mathrm{wt} \%$ in an attempt to improve the gypsum solids properties further. Although the greater residence time and solids concentration gave improved form filtration rates, the filter leaf cake concentration and thickener unit area results deteriorated slightly. At this point, it does not appear that the higher solids concentration is beneficial to the gypsum solids properties. This effect may be related to the higher crystal attrition associated with a higher number of passes through the recirculation pumps and a higher solids concentration.

\section{Effect of Pre-mix Tank}

To increase the dispersion rate of the lime reagent even further, a pre-mix tank was installed near the pilot reaction tank. The $25 \mathrm{wt} \%$ lime reagent was fed to the premix tank where it was mixed with $30 \mathrm{wt} \%$ slurry recirculating from the reaction tank. The lime/gypsum mixture was then fed to the reaction tank to control the $\mathrm{pH}$ at 5.5. A sample from the pre-mix tank showed the mixture to be $31.6 \mathrm{wt} \%$ solids suggesting that some of the gypsum was precipitating in the pre-mix tank. Table 8 summarizes the pre-mix tank results. Test results before and after the pre-mix tank was installed showed that, with the pre-mix tank, the solids properties improved with respect to filter leaf cake concentration and thickener unit area and were consistently high with respect to the form filtration rate. Additionally, the calcium sulfite RS value decreased from 1.67 to 1.02 after the installation of the pre-mix tank. Overall, lime reagent dispersion in the reaction tank appears to be extremely important to gypsum solids quality.

\section{FUTURE TESTS}

The ECTC will have an outage in June to install new duct and new fan blades in preparation for high velocity testing later this year. The outage will suspend testing for approximately 12 days.

After the outage, the Trace Element Removal test block which began in April will continue. Testing in June will examine mercury removal across a wet scrubber operating under various system conditions. Impinger testing will also continue. To ensure that condensation of elemental mercury vapor did not occur previously, elemental mercury will be spiked after the second impinger while sampling ambient air. During a second test, elemental mercury will be spiked into a gas sampling train after collecting a flue gas inlet sample (rather than spiking the mercury simultaneously as done in May). This test will help determine if mercury capture in the peroxide impingers is affected dynamically by the presence of flue gas components or by impinger solution effects.

Additionally, six weeks of LDG testing will be conducted simultaneously with the TER test block. Initial tests will investigate the possibility of using limestone with a 
very short solids residence time (similar to many dual alkali systems). After the outage, the mini-pilot MRT will be configured at the pilot reaction tank to better simulate a smaller reaction tank and the associated reaction tank chemistry. 


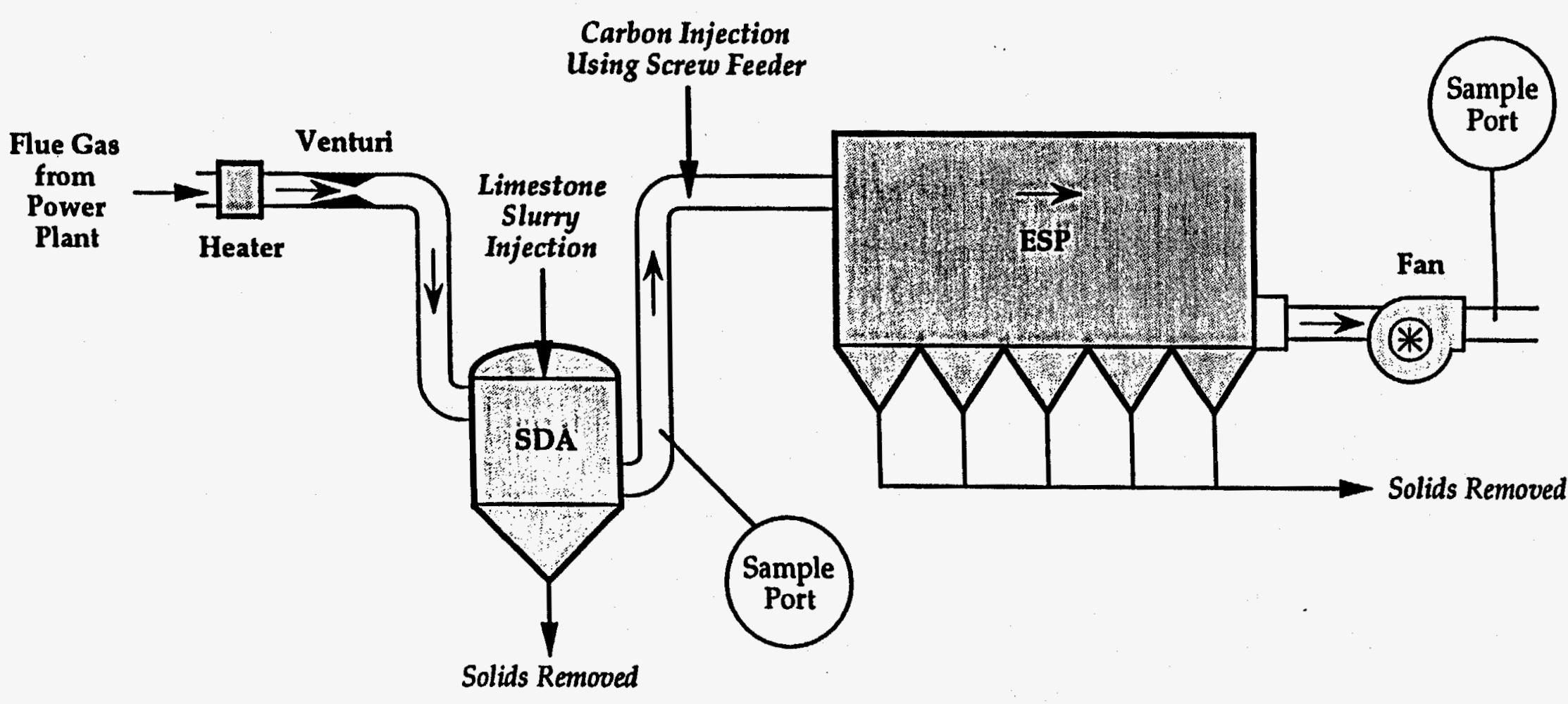




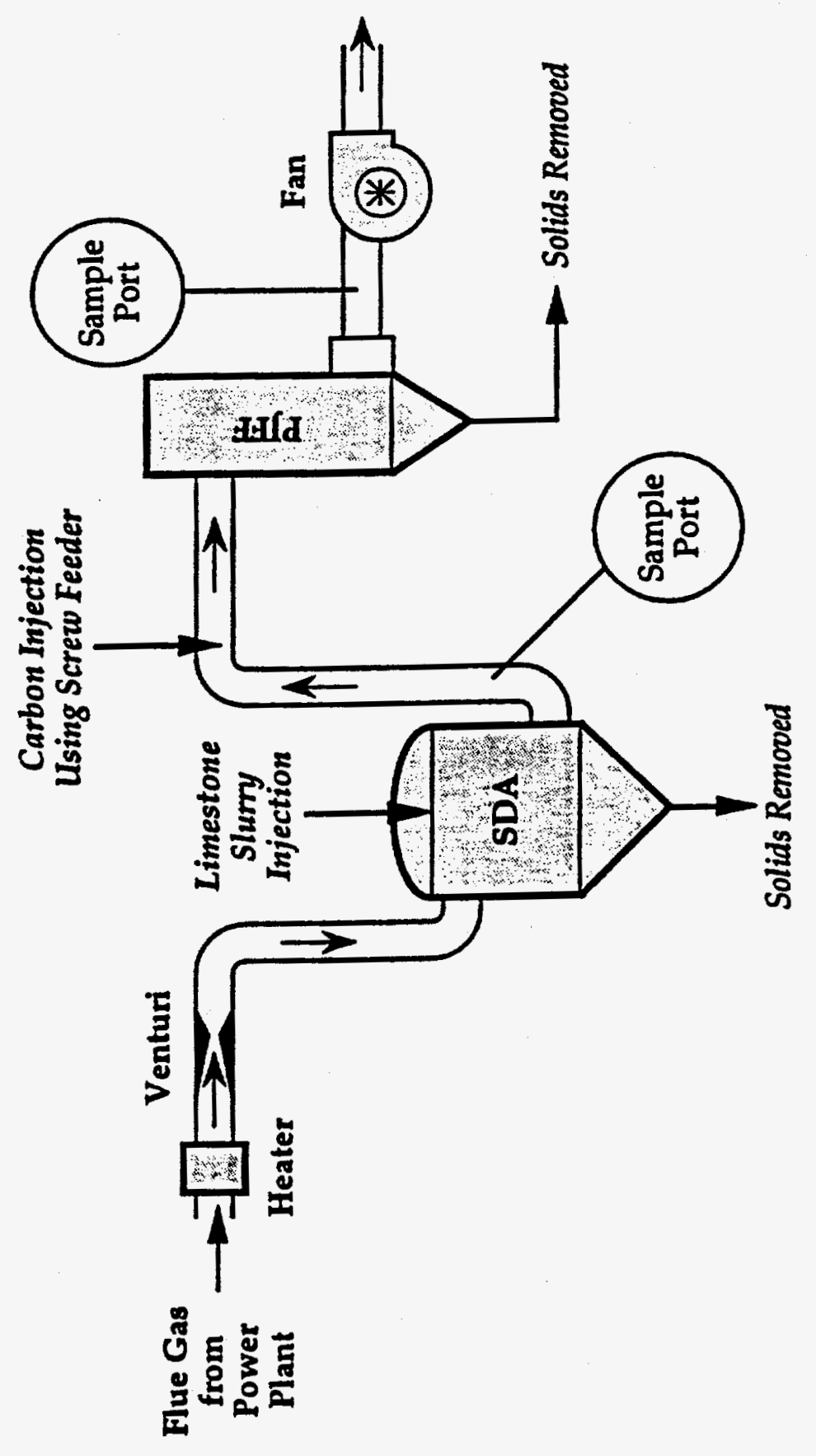

0 


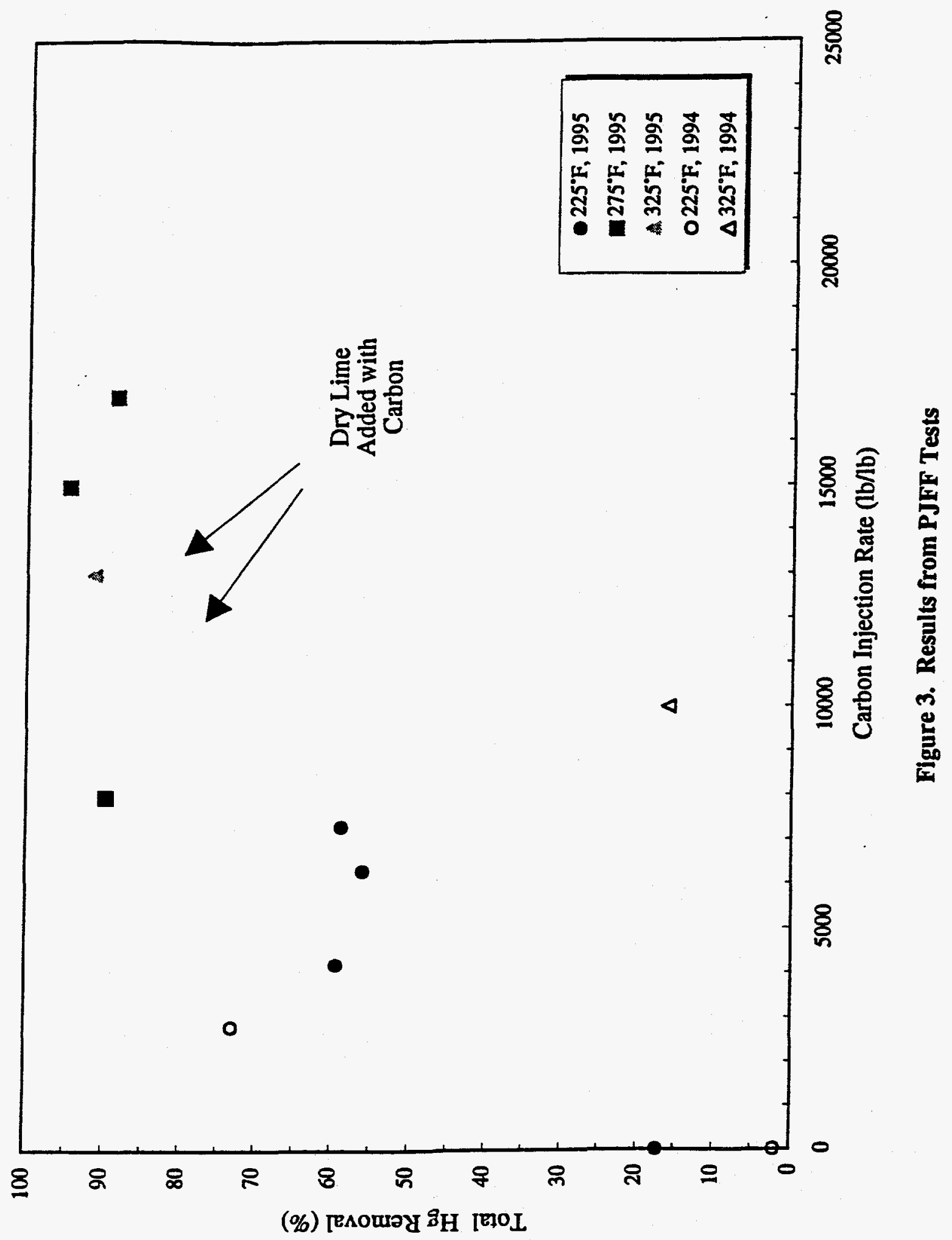




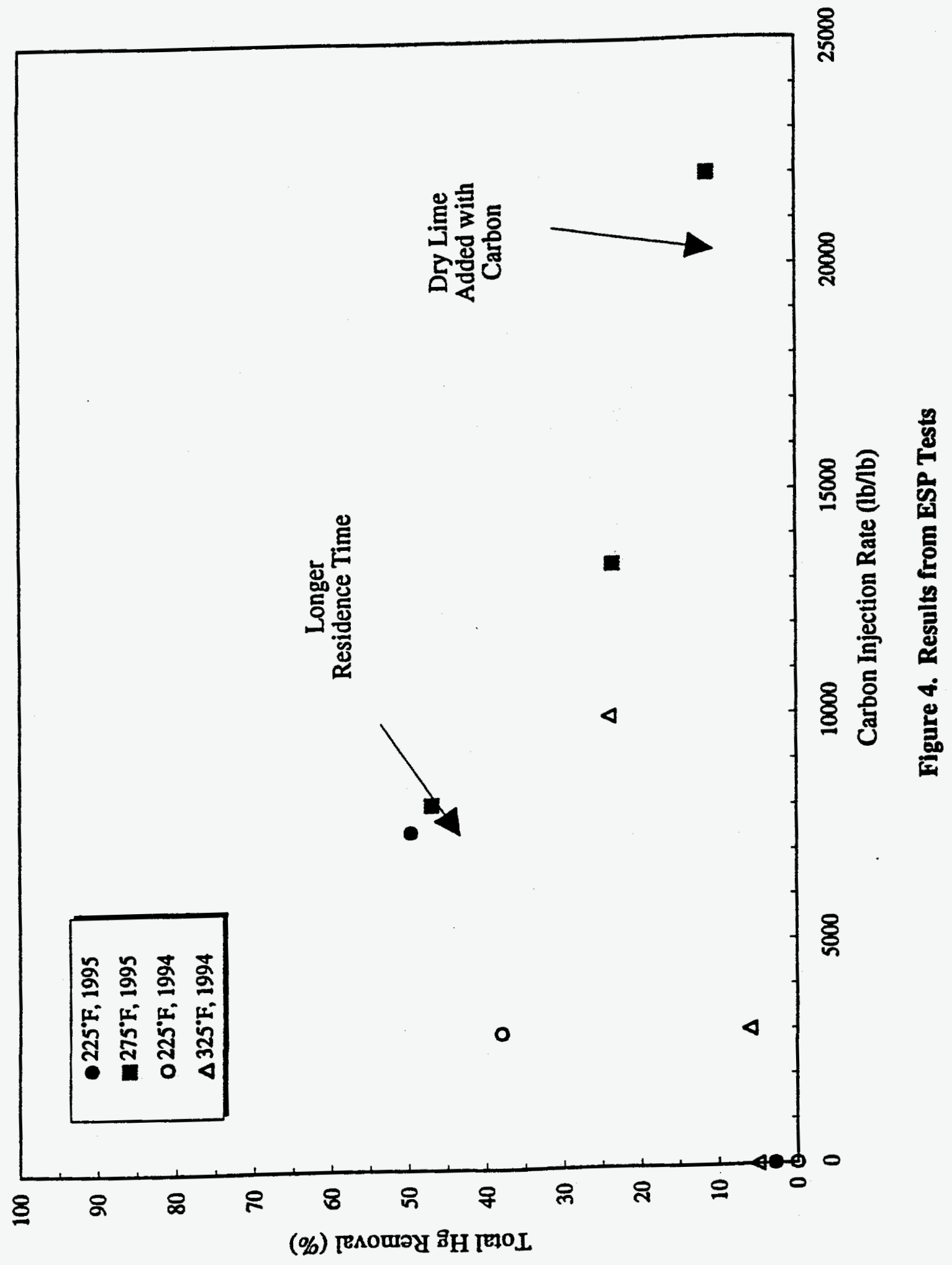




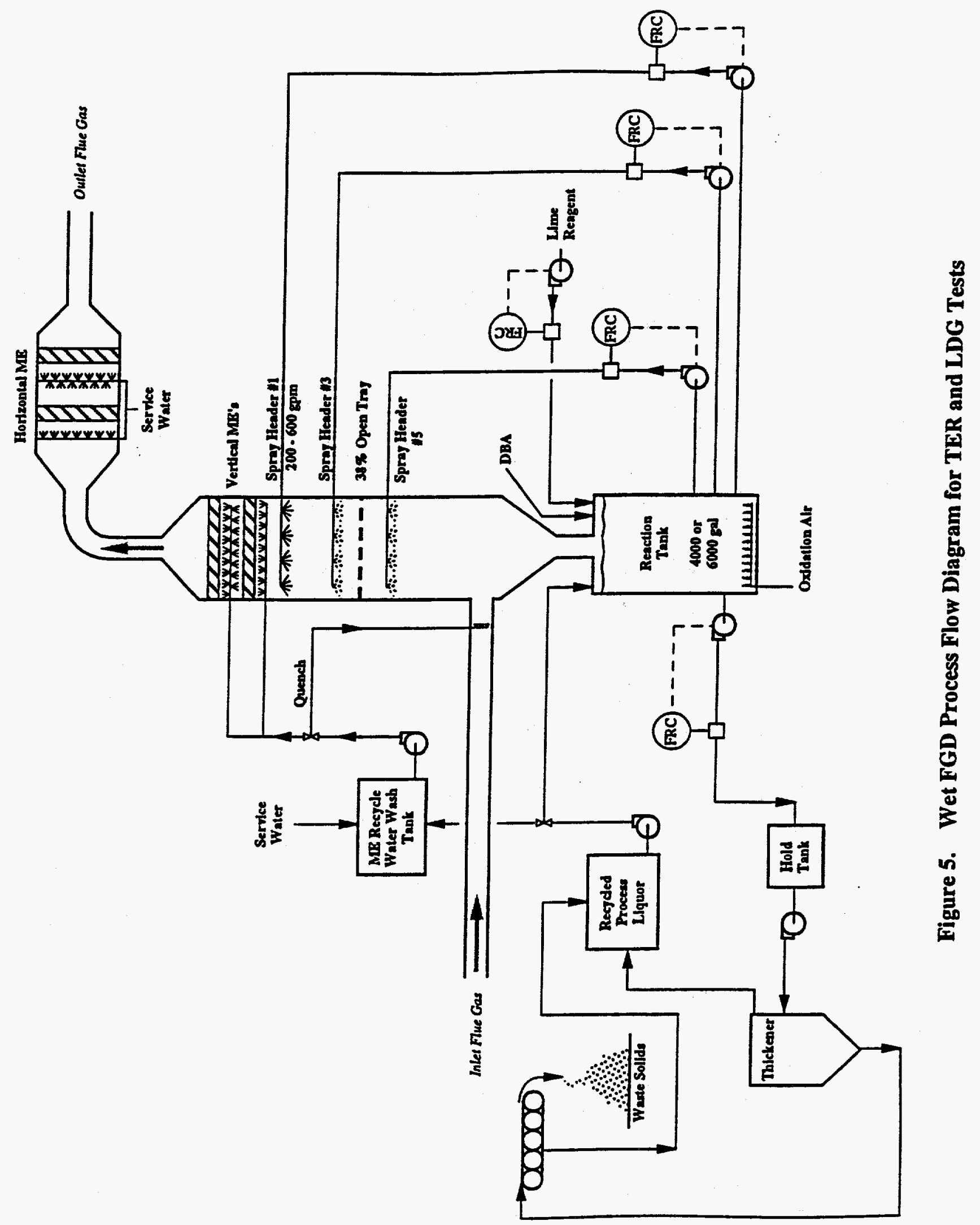




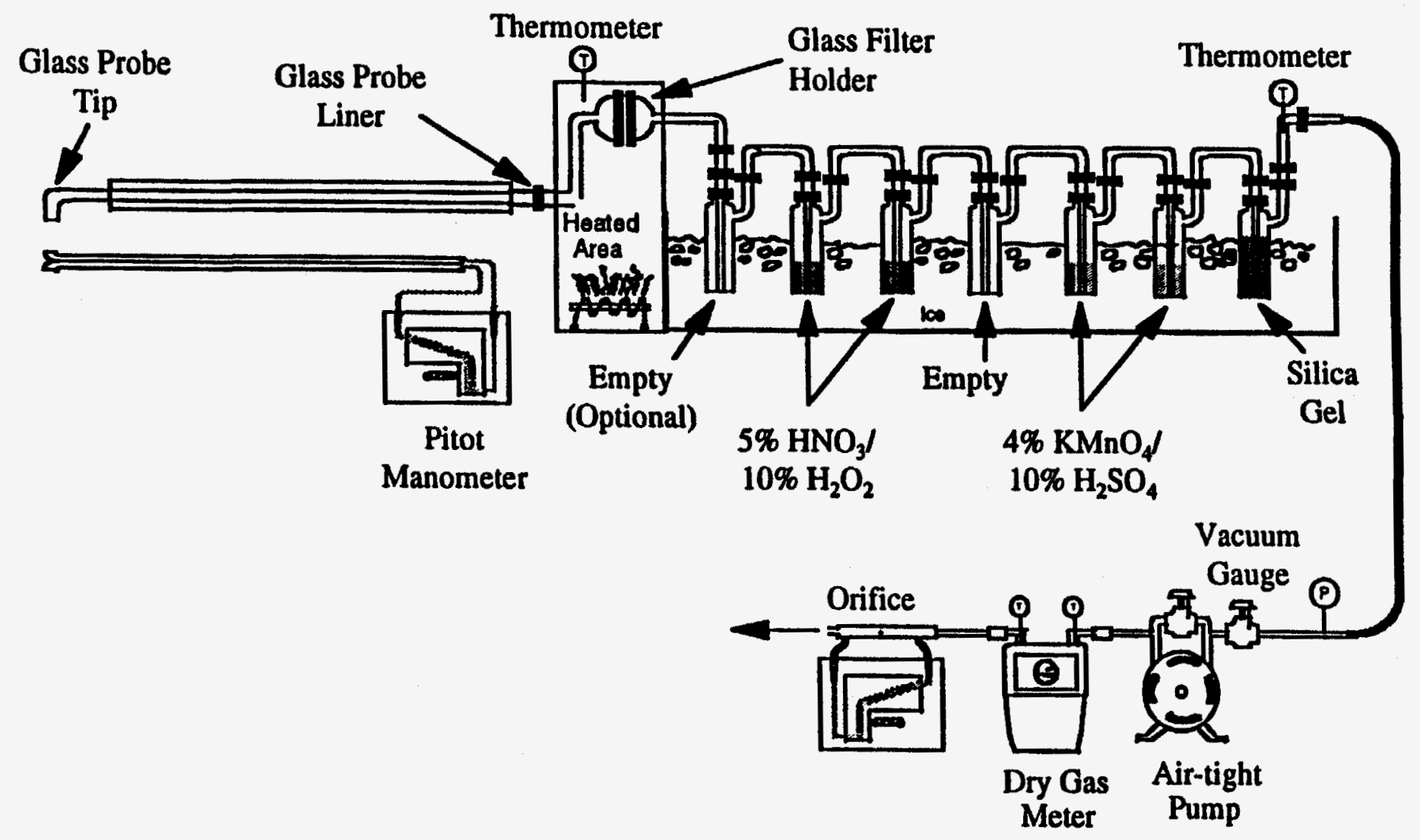




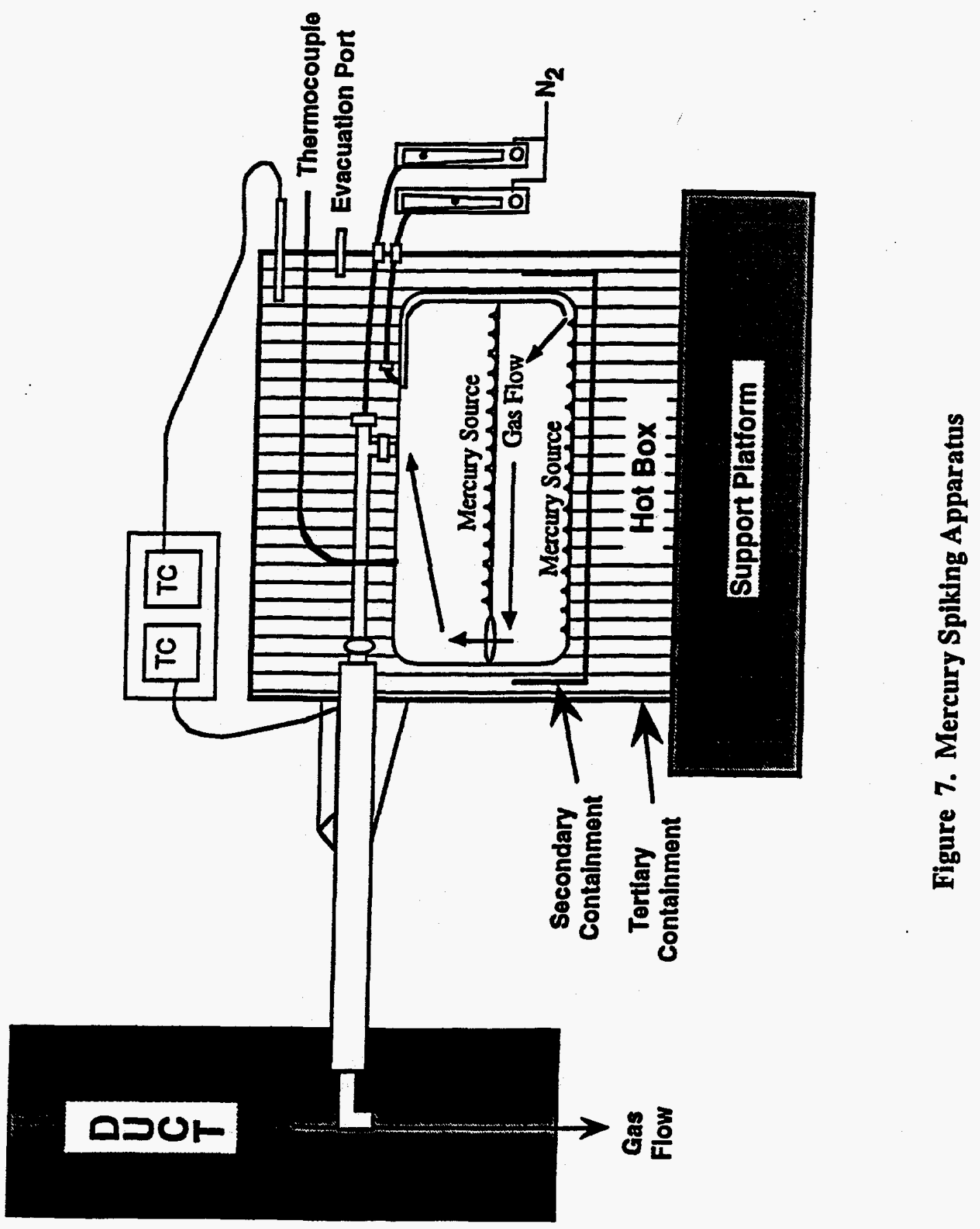




\section{May Operating Summary}

\begin{tabular}{|c|c|c|c|}
\hline Date & & Process Summary & Gas Summary \\
\hline $\begin{array}{l}\text { Mon } \\
5 / 1\end{array}$ & $\begin{array}{l}\text { PJFF- } 2 \mathrm{X} \\
4500 \text { sefm, } 225^{\circ} \mathrm{F} \\
\text { inlet temp. } \\
6 \text { in. } \mathrm{H}_{2} \mathrm{O} \mathrm{dP} \text {. } \\
0.51 \mathrm{lb} / \mathrm{hr} \\
\text { carbon injection }\end{array}$ & $\begin{array}{l}\text { Adjustments made to the CEM cabinets. } \\
\text { Figh particulate concentration found at the } \\
\text { PJFF outlet led to bringing unit down to } \\
\text { check for leals in the PJFF. }\end{array}$ & $\begin{array}{l}\text { Sampling at the PJFF iniet and } \\
\text { at the PJFF outlet. Two } \\
\text { peroxide impingers recovered } \\
\text { together were used. }\end{array}$ \\
\hline $\begin{array}{l}\text { Tue } \\
5 / 2\end{array}$ & $\begin{array}{l}\text { Unit down to check } \\
\text { for PJFF leaks. }\end{array}$ & $\begin{array}{l}\text { Performed Visalite test. Found leaks at } \\
\text { several places at blank plates and at } \\
\text { flanges of newhy installed bags. RTV } 736 \\
\text { sealant applied around blank caps and put } \\
\text { a bolt and seaime in the fiangea. }\end{array}$ & $\begin{array}{l}\text { Ambiem air sample which used } \\
4 \text { peraxide impingers recovered } \\
\text { individually. Mercury spiking } \\
\text { befoce the first impinger. }\end{array}$ \\
\hline $\begin{array}{l}\text { Wed. } \\
5 / 3\end{array}$ & & 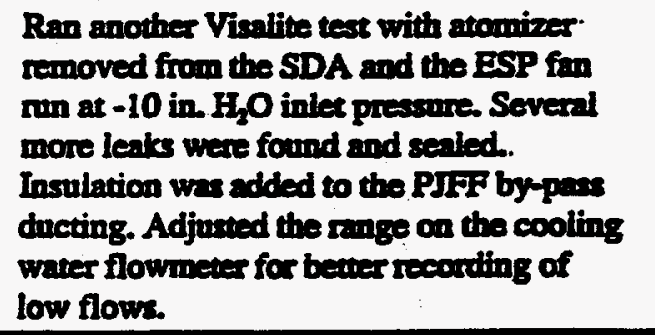 & \\
\hline $\begin{array}{l}\text { Thur. } \\
5 / 4\end{array}$ & $\begin{array}{l}\text { PJFF-2R } \\
4500 \text { sefin, } 225^{\circ} \mathrm{F} \\
\text { inlet temp. } \\
6 \text { in. } \mathrm{H}_{2} \mathrm{O} \mathrm{dP} \\
0.51 \mathrm{lb} / \mathrm{hr} \\
\text { carbon injection }\end{array}$ & 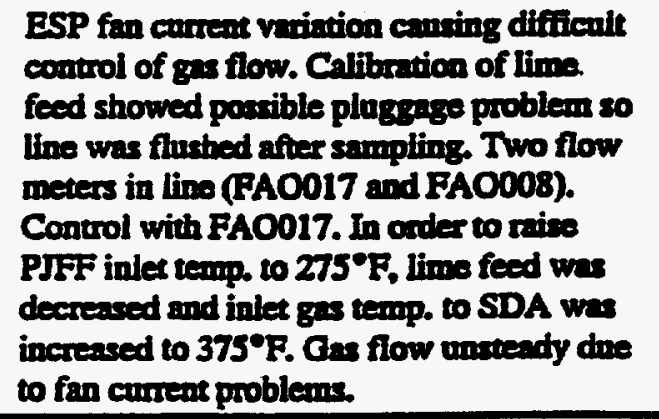 & $\begin{array}{l}\text { Gas sampling at the PJFF inlet } \\
\text { and at the PJFF outlet. Two } \\
\text { peroxide impingers recovered } \\
\text { cogether were used. }\end{array}$ \\
\hline $\begin{array}{l}\text { Fri. } \\
5 / 5\end{array}$ & $\begin{array}{l}\text { PJFF-3 } \\
4270 \text { scfm, } 275^{\circ} \mathrm{F} \\
\text { inlet temp. } \\
4 \mathrm{in} . \mathrm{H}_{2} \mathrm{O} \mathrm{dP} \\
1.28 \mathrm{lb} / \mathrm{hr} \text { carbon } \\
\text { injection }\end{array}$ & 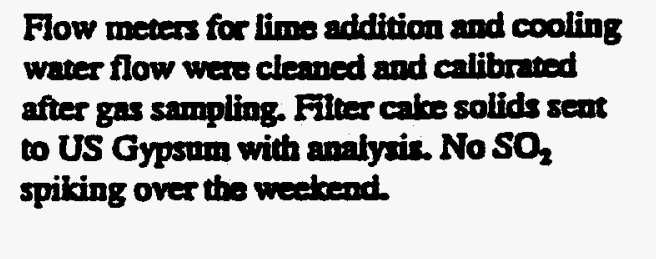 & $\begin{array}{l}\text { Gas sampling at the PJFF iniet } \\
\text { and outlet. Used } 2 \text { peroxide } \\
\text { impingers, recovered together. }\end{array}$ \\
\hline $\begin{array}{l}\text { Sat. } \\
5 / 6\end{array}$ & & $\begin{array}{l}\text { ESP fan corrent is erratic Switched to } \\
\text { manual control ( } 40 \mathrm{~Hz} \text { is an umamble } \\
\text { operaring point for the ESP's variable } \\
\text { speed drive). }\end{array}$ & \\
\hline $\begin{array}{l}\text { Sun. } \\
5 \pi\end{array}$ & & $\begin{array}{l}\text { NYSEG load variation contributing to } \\
\text { problems with the ESP fan. Batching dry } \\
\text { hydrated lime and carbon at 2:1 ratio ( } 25 \\
\text { lbs lime and } 12.5 \text { lbs. carbon). }\end{array}$ & • \\
\hline
\end{tabular}




\section{May Operating Summary}

\begin{tabular}{|c|c|c|c|}
\hline Date & & Process Strmmary & Cas Summary \\
\hline $\begin{array}{l}\text { Mon. } \\
\mathbf{5 8}\end{array}$ & $\begin{array}{l}\text { PJFF-4 } \\
4270 \text { sefm, } 275^{\circ} \mathrm{F} \\
\text { inlet temp. } \\
4 \text { in. } \mathrm{H}_{2} \mathrm{O} \mathrm{dP} \\
3.84 \mathrm{lb} / \mathrm{hr} \text { carbon } \\
\text { injection }\end{array}$ & $\begin{array}{l}\text { Running ESP fan in local control (i.e, at } \\
\text { the VSD station). To achieve } 325^{\circ} \mathrm{F} \text {, the } \\
\text { lime feed to the atomizer was shut off. } \\
\text { Vibrator activated on the hopper of the } \\
\text { serew feeder to prevent "rat holing". } \\
\text { Observed that flows with serew feeder are } \\
\text { more constant when hopper is kept full. }\end{array}$ & $\begin{array}{l}\text { Gas sampling at the PJFF inlet } \\
\text { and outlet. Used } 2 \text { peroxide } \\
\text { impingers, recovered together. }\end{array}$ \\
\hline $\begin{array}{l}\text { The. } \\
5 \% 9\end{array}$ & $\begin{array}{l}4070 \text { scim } \\
325^{\circ} \mathrm{F} \text { iniet temp. } \\
4 \text { in. } \mathrm{H}_{2} \mathrm{O} \mathrm{dP} \\
3.66 \mathrm{lb} / \mathrm{hr} \text { cartoun } \\
\text { injection }\end{array}$ & $\begin{array}{l}\text { By-pass damper was partially closed in } \\
\text { oxder to operate the ESP's VSD at a } \\
\text { frequency where anto control could be } \\
\text { maintained. SDA solids bin leals ash } \\
\text { when the vibrator is used. }\end{array}$ & $\begin{array}{l}\text { Gas sampling at the PJFF inlet } \\
\text { and cuttet. Used } 2 \text { peroxide } \\
\text { inapingers, recovered together. }\end{array}$ \\
\hline $\begin{array}{l}\text { Wed. } \\
\text { s/10 }\end{array}$ & $\begin{array}{l}\text { PJFF-3R } \\
4270 \text { scfin } \\
275^{\circ} \mathrm{F} \text { inlet temp. } \\
4 \mathrm{in.} \mathrm{H}_{2} \mathrm{O} \mathrm{dP} \\
0.64 \mathrm{lb} / \mathrm{hr} \text { carbon } \\
\text { injection }\end{array}$ & 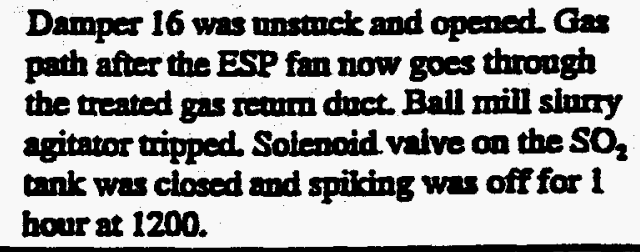 & $\begin{array}{l}\text { Gas sampling at the PJFF inlet } \\
\text { and outlet. Used } 2 \text { peroxide } \\
\text { impingers, recovered together. }\end{array}$ \\
\hline $\begin{array}{l}\text { Thur. } \\
\text { 5/11 }\end{array}$ & $\begin{array}{l}\text { PJFF-2RR } \\
4500 \text { sctim } \\
225^{\circ} \mathrm{F} \text { inlet temp. } \\
6 \mathrm{in} . \mathrm{H}_{2} \mathrm{O} \text { dP } \\
0.33 \mathrm{lb} / \mathrm{hr} \text { carbon } \\
\text { injection }\end{array}$ & $\begin{array}{l}\text { Carbon serew feeder motor pue at lowest } \\
\text { setuing. Unit brought down after test to } \\
\text { configure for the ESP test. The PJFF was } \\
\text { pulse-cleawed on-line and then off-line to } \\
\text { purge remaining } \mathrm{SO}_{2} \text { gas. Ancor repaired } \\
\text { VME wash header flanges for the upper } \\
\text { and lower VME using single-piece } \\
\text { flanges. }\end{array}$ & $\begin{array}{l}\text { Gas sampling at the PJFF inlet } \\
\text { and outlet. Used } 2 \text { pecoxide } \\
\text { impingers, recovered together. }\end{array}$ \\
\hline $\begin{array}{l}\text { Fri. } \\
\text { Sn2 }\end{array}$ & $\begin{array}{l}\text { Unit down for } \\
\text { modifications to run } \\
\text { ESP tests. }\end{array}$ & $\begin{array}{l}\text { Blanking plates put in place to isolnte the } \\
\text { PJFF and eatublish gas path through the } \\
\text { ESP. CEM probe in place for the PJFF } \\
\text { tests now cut of the gas path. Whil use } \\
\text { facility out CEM probe for ESP ondlet } \\
\text { measurement of } \mathrm{O}_{2} \text { and } \mathrm{SO}_{2} \\
\text { concentrations. }\end{array}$ & $\begin{array}{l}\text { Gas sampling at the PIFF inlet } \\
\text { and outlet. Used } 2 \text { peroxide. } \\
\text { impingers, recovered together. }\end{array}$ \\
\hline $\begin{array}{l}\text { Sat. } \\
5 \pi 3\end{array}$ & & $\begin{array}{l}\text { ESP fan trips to mamual periodically. } \\
\text { Cooling warer rate exceeds range of flow } \\
\text { meter so flow run in manual. }\end{array}$ & \\
\hline $\begin{array}{l}\text { Sun. } \\
\text { s/14 }\end{array}$ & & $\begin{array}{l}\text { Cleaned test port on TGR duct at pilot } \\
\text { level. Blew out pressure taps at CRG } \\
\text { supply duct and SDA pressure tap. }\end{array}$ & \\
\hline $\begin{array}{l}\text { Mon. } \\
5 / 15\end{array}$ & $\begin{array}{l}\text { ESP-1 } \\
10200 \text { scfm } \\
225^{\circ} \mathrm{F} \text { iniet temp. }\end{array}$ & $\begin{array}{l}\text { CEMs spanned to } 7 \% \text { at the SDA outlet } \\
\text { and } 8.99 \% \text { at the facility outlet }\end{array}$ & $\begin{array}{l}\text { Gas sarmpling at the ESP iniet } \\
\text { and at the facility outlet. }\end{array}$ \\
\hline
\end{tabular}




\begin{tabular}{|c|c|c|c|}
\hline Date & & Process Summary & Ges Summary \\
\hline $\begin{array}{l}\text { The. } \\
5116\end{array}$ & $\begin{array}{l}\text { ESP-2 } \\
10200 \text { sefim } \\
225^{\circ} \mathrm{F} \text { inlet teup. }\end{array}$ & $\begin{array}{l}\text { Venturi ports at the SDA inlet were } \\
\text { "rodded out" and the venturi was } \\
\text { calibrated. Solids from the SDA bottom } \\
\text { are vacunmed out becanse evacuaticn } \\
\text { system was not woriding. }\end{array}$ & $\begin{array}{l}\text { Gas sampling at the ESP inlet } \\
\text { and at the facility outlet. }\end{array}$ \\
\hline $\begin{array}{l}\text { Wed. } \\
\text { S177 }\end{array}$ & $\begin{array}{l}\text { ESP-3 } \\
9700 \text { scim } \\
275^{\circ} \mathrm{F} \text { iniet temp. }\end{array}$ & $\begin{array}{l}\text { Inlet and outlet SDA aspirators were: } \\
\text { flushed. }\end{array}$ & $\begin{array}{l}\text { Cas sampling at the ESP inlet } \\
\text { and at the facility outlet. }\end{array}$ \\
\hline $\begin{array}{l}\text { Thar. } \\
\text { s/18 }\end{array}$ & $\begin{array}{l}\text { ESP-4 } \\
4270 \text { sefin } \\
275^{\circ} \text { F iniet temp. }\end{array}$ & 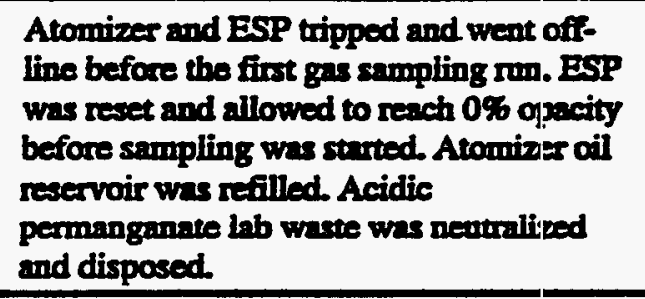 & $\begin{array}{l}\text { Cas sampling at the ESP iniet } \\
\text { and at the facility outlet. }\end{array}$ \\
\hline $\begin{array}{l}\text { Fri. } \\
5 / 19\end{array}$ & $\begin{array}{l}\text { ESP-5 } \\
9700^{\text {sefm }} \\
275^{\circ} \mathrm{F} \text { iniet temp. }\end{array}$ & $\begin{array}{l}\text { At conclusion of teating, dinty raw gas was } \\
\text { set to run through the ESP. The ESP was } \\
\text { set to rap at increared frequency to } \\
\text { eliminate accumiated miterial from the } \\
\text { plates. Installed belt on piloc centrifuge. }\end{array}$ & $\begin{array}{l}\text { Sampling at the ESP inlet and } \\
\text { at the Facility outlet. Two } \\
\text { peroxide impingers, recovered } \\
\text { together, were used. }\end{array}$ \\
\hline $\begin{array}{l}\text { Sat. } \\
5 / 20\end{array}$ & & $\begin{array}{l}\text { Preparation for modification of PFIRT } \\
\text { reagent feed system. Slumy from PFLRT } \\
\text { transfered to MRT. PFIRT filled and } \\
\text { flushed and solids clened ont. Underflow } \\
\text { storage tank cleaned ont. ESP drive } \\
\text { ripped. Shut ofT incoming ge flow. }\end{array}$ & \\
\hline $\begin{array}{l}\text { Sun. } \\
5 / 21\end{array}$ & & $\begin{array}{l}\text { Cleaned PFLRT sparger ring and teated } \\
\text { with air in water. Pulling gas. }\end{array}$ & \\
\hline $\begin{array}{l}\text { Mon } \\
5 / 22\end{array}$ & $\begin{array}{l}\text { T4 } \\
11000 \mathrm{scfm} \\
\mathrm{LG}=30 \\
10000 \mathrm{ppm} \mathrm{Mg} \\
50 \mathrm{ppm} \mathrm{Mn} \\
25 \text { wts }\end{array}$ & 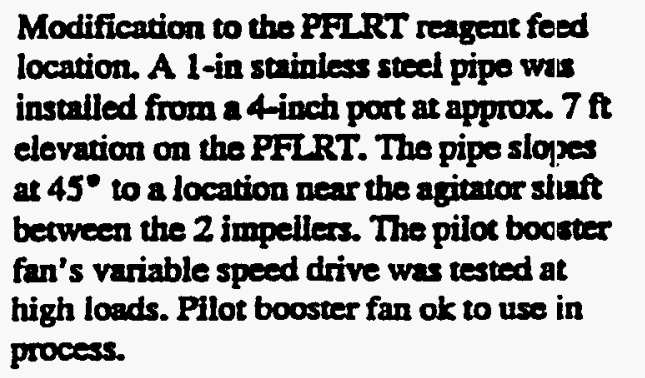 & \\
\hline
\end{tabular}


Table 1

May Operating Summary

Date

Process Summary

Gas Summary

Tue.

Preventive maintenance done on air

$5 \longdiv { 2 3 }$

compressors which included lowering

oxidation air to 300 sefm for 15 minutes.

Vacuum belt filter (VBF) tripped. WDPF

slurry weight $\%$ was $18 \%$ different from

measured value. Catibration check of

blowdown to smmp and quench pumps.

Repaired end bell of the carbon injection nomile.

Wed. T4-IY

524

Calibration check of ME wash and reagent feed. Slunry measured weight. $\%$ was $13 \%$ off from WDPF value Centrifuge motor re-installed and checked out Instument air for FCV-4 (reagent feed) broke and valve failed closed. Control by-passed until repaired. Collins filter media replaced

Comparison sample at the wet scrubber inlet. Four peroxide impingers, recovered individually, were utilized. Spiking before the first impinger. at the PFLRT sink. Velocity traverse performed at the pilot inilet.

Thur.

Changed flow path of slip stream taken for $5 / 25$ pH and density measurements. The stream now flows past the pH probe then enters the density meter at the bottom and flowe vertically through the meter. Slung weight\% was within 3\% of WDPF value Modified lab density program to change density meter constunt to control density to within $\pm 2 \%$. Polymer flow increased due to dirty overflow. Added three 5-gallon batches of polymer to thickener to help clear the overflow.

\begin{tabular}{lll}
\hline Fri. & T5-IZ & $\begin{array}{l}\text { Blaniking plate installed to enable repair } \\
\text { work on fabric filter fan. Gas by-passing } \\
\text { absorber for approximately } 1 \text { hour. }\end{array}$
\end{tabular}

This was a comparison sample taken at the wet serubber outlet. Four peroxide impingers, recovered individually, were used. Mercory was spiked between the second and thind impingers. During the second run, the mercury spiking apparams fell off and was replaced after an undetermined time After the mercury spiking tobe was replaced, mercury was spiked for 20 minutes. 


\section{May Operating Summary}

\begin{tabular}{|c|c|c|c|}
\hline Date & & Process Summary & Gas Summary \\
\hline $\begin{array}{l}\text { Sat. } \\
5 / 27\end{array}$ & $\begin{array}{l}\text { TS } \\
11000 \text { sefm } \\
\text { UG }=30 \\
30 w t \%\end{array}$ & $\begin{array}{l}\text { Maintained conditions for T5 throughout } \\
\text { weekend. FCV-19 leaks when washing } \\
\text { mist eliminators }\end{array}$ & \\
\hline $\begin{array}{l}\text { Sun. } \\
5 / 28\end{array}$ & & $\begin{array}{l}\text { Level I thickener dropped below weir level } \\
\text { for overflow. Blowdown to VBF } \\
\text { shutdown to build level in the thickeater. }\end{array}$ & \\
\hline $\begin{array}{l}\text { Mon. } \\
5 / 29\end{array}$ & & $\begin{array}{l}1700 \text { gallons transferred from the SDA } \\
\text { RSST to the pilot RSST. Spiked } 50 \text { lbs } \\
\text { MgOH per foot of transferred shury. } \\
\text { Water added to the recycle water tank } \\
\text { because of low level. }\end{array}$ & \\
\hline $\begin{array}{l}\text { Tue. } \\
5 / 30\end{array}$ & $\begin{array}{l}\text { T6 } \\
11000 \text { scfin } \\
\text { pre-mix tank }\end{array}$ & $\begin{array}{l}\text { Finals collected for T5. Gas flows } \\
\text { decreased after sampling to help clear } \\
\text { water collected in the revurn duct to } \\
\text { NYSEG. Replaced drain hose because of } \\
\text { pluggage. Configuring syatem to put hold } \\
\text { tank in service as a pre-mix tank for the } \\
\text { lime reagent. }\end{array}$ & \\
\hline $\begin{array}{l}\text { Wed. } \\
5 / 31\end{array}$ & T6-JZ & $\begin{array}{l}\text { Pilot queneh flow was low. Cycled pump } \\
\text { and got flow back to set point. ESP field } \\
\text { "A" tripped off after high hopper signal. } \\
\text { Internal hose on pump } 13 \text { brote. Using } \\
\text { chemical addition pump for flow from pre- } \\
\text { mix tank to the PFLRT. Replaced leationg } \\
\text { discharge connection on chemical addition } \\
\text { pump. Chemical addition pump does not } \\
\text { have variable speed drive, so control of } \\
\text { diluted lime reagent to PFLRT is less } \\
\text { accurate. }\end{array}$ & $\begin{array}{l}\text { This was a comparison sample } \\
\text { at the wet serubber outlet. Four } \\
\text { peroxide impingers were used } \\
\text { for all nuns. The first two } \\
\text { peroxides were recovered } \\
\text { together, and the next two were } \\
\text { recovered together. }\end{array}$ \\
\hline
\end{tabular}


Summary of Carbon Injection Test Conditions and Results

\begin{tabular}{|c|c|c|c|c|c|c|c|c|c|}
\hline $\begin{array}{c}\text { Test } \\
\text { ID }\end{array}$ & $\begin{array}{c}\text { Gas } \\
\text { Temp } \\
\left({ }^{\circ} \mathbf{F}\right)\end{array}$ & $\begin{array}{c}\text { Carbon } \\
\text { Inject. } \\
\text { Ratio } \\
\text { (lb:lb) }\end{array}$ & $\begin{array}{c}2: 1 \\
\text { Carbon } \\
\text { Lime }\end{array}$ & $\begin{array}{l}\text { Reagent } \\
\text { Feed to } \\
\text { Atomizer } \\
(\mathrm{lb} / \mathrm{hr})\end{array}$ & $\begin{array}{c}\text { Gas } \\
\text { Residence } \\
\text { Time } \\
\text { (sec) }\end{array}$ & $\begin{array}{c}\text { PJFF } \\
\text { Pressure } \\
\text { Drop } \\
\text { (in. } \mathbf{H , O} \mathbf{O}\end{array}$ & $\begin{array}{c}\text { ESP } \\
\text { SCA } \\
\left(\mathrm{ft}^{2} / \mathrm{kacfm}\right)\end{array}$ & $\begin{array}{c}\text { Total Hg } \\
\text { Removal } \\
(\%)\end{array}$ & $\begin{array}{c}\text { Vapor } \mathrm{Hg} \\
\text { Removal } \\
(\%)\end{array}$ \\
\hline
\end{tabular}

\section{PJFF Tests}

$\begin{array}{lccccccccc}\text { PJFF-1 } & 225 & 0 & \text { no } & 18.5 & \text { NA } & 4.9 & \text { NA } & 17 & 6 \\ \text { PJFF-2X } & 225 & 6,300 & \text { no } & 18.3 & 3.9 & 5.6 & \text { NA } & 56 & 49 \\ \text { PJFF-2R } & 225 & 7,300 & \text { no } & 20.5 & 3.9 & 5.6 & \text { NA } & 59 & 54 \\ \text { PJFF-2RR } & 225 & 4,200 & \text { no } & 7.2 & 3.9 & 5.8 & \text { NA } & 59 & 51 \\ \text { PJFF-3X } & 275 & 17,000 & \text { no } & 13.8 & 3.9 & 3.8 & \text { NA } & 89 & 89 \\ \text { PJFF-3R } & 275 & 8,000 & \text { no } & 7.2 & 3.9 & 3.8 & \text { NA } & 90 & 91 \\ \text { PJFF-4 } & 275 & 15,000 & \text { yes } & 13.8 & 3.9 & 3.8 & \text { NA } & 95 & 95 \\ \text { PJFF-5 } & 325 & 13,000 & \text { yes } & 0.0 & 3.9 & 3.8 & \text { NA } & 91 & 92\end{array}$

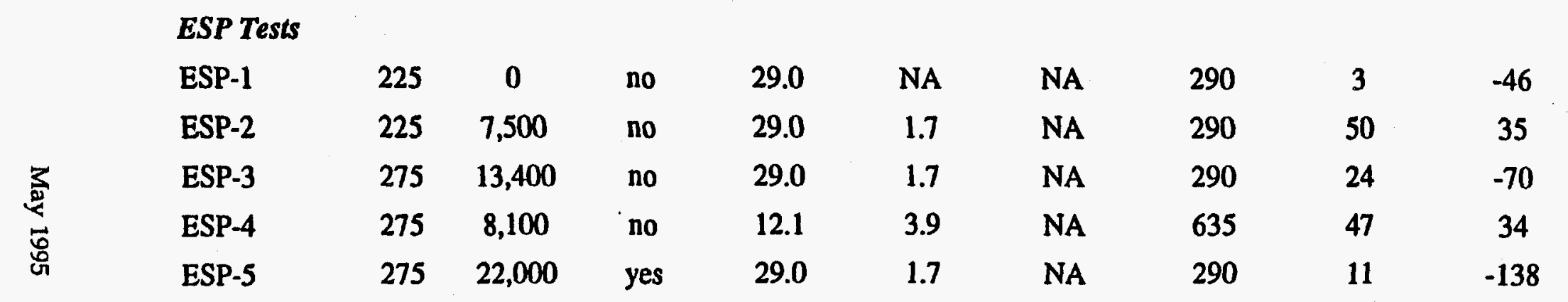




\begin{tabular}{|c|c|c|c|c|c|c|c|}
\hline әp!xoded & sod & sad & ग|! SM & $(0)^{8} \mathrm{H}$ & ฑリய! SM & 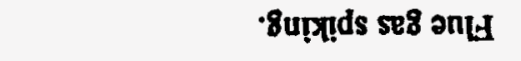 & XI-LI \\
\hline әp!xorad & ${ }^{\mathbf{s}} \mathrm{X}$ & ON & -dun puz IOIJ & $(0)^{8} \mathrm{H}$ & JPIu! SM & 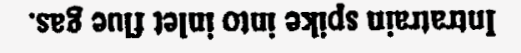 & $\lambda[-9 . \mathbf{L}$ \\
\hline әр!х019d & sad & oN & du! puz गI5 & $(0)^{8} \mathbf{H}$ & эәрп⿱ SM & 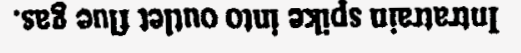 & $\mathrm{ZC}-9 \mathrm{ll}$ \\
\hline әplxored & $\operatorname{sed}$ & $\mathbf{O N}$ & du! ISI 210Jag & $(0)^{8} \mathrm{H}$ & Ppno SM & 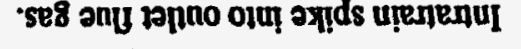 & $\mathbf{Z 1}=\mathbf{S 1}$ \\
\hline әpIxosed & SoX & $\mathbf{O N}$ & |du్f 1SI 2rojəg & $(0)^{8} \mathrm{H}$ & गणप! SM & 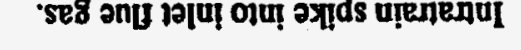 & 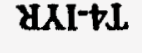 \\
\hline әp!xo19d & $\operatorname{sox}$ & on & 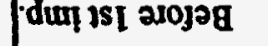 & $(0)^{8} \mathrm{H}$ & I! & 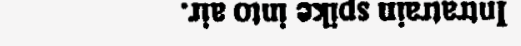 & V1-aL \\
\hline $\begin{array}{c}\text { dur edjXg } \\
\text { jo u,jos }\end{array}$ & 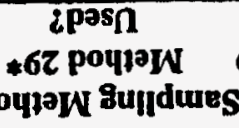 & $\begin{array}{l}\text { ¿pasn } \\
62 \text { poy10w } \\
5\end{array}$ & $\begin{array}{l}\text { uolpeso I } \\
\text { sy|dS } \\
\text { suopupuos }\end{array}$ & $\begin{array}{l}\text { parlds } \\
\text { sapords } \\
\text { aupids }\end{array}$ & $\begin{array}{l}\operatorname{rdkL} \\
\text { गdures } \\
\text { seg }\end{array}$ & 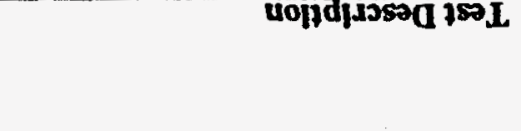 & $\underset{\mid \leq ⿻ 上 丨}{\mathbf{d i l}}$ \\
\hline
\end{tabular}

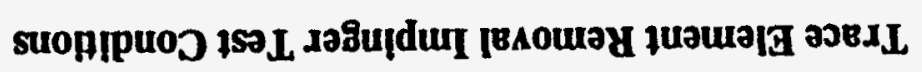

E गq8L 
Table 4

Comparison Between Method 29 and Method 29* With and Without Flue Gas Mercury Spiking (T1-NX, T7-EY)

\begin{tabular}{|c|c|c|c|c|c|c|c|}
\hline \multirow[b]{2}{*}{$\begin{array}{c}\text { Sampling } \\
\text { Method }\end{array}$} & \multirow[b]{2}{*}{$\begin{array}{l}\text { Sampling } \\
\text { Location }\end{array}$} & \multirow[b]{2}{*}{$\begin{array}{c}\text { Total } \\
\text { Mercury } \\
\left(\mu g / \mathrm{Nm}^{3}\right)\end{array}$} & \multicolumn{5}{|c|}{ Total Mercury Capture by Impinger } \\
\hline & & & $\begin{array}{c}1 \\
\mathrm{H}_{2} \mathrm{O}_{2} \\
(\% \text { of total } \mathrm{Hg})\end{array}$ & $\begin{array}{c}2 \\
\mathrm{H}_{2} \mathrm{O}_{2} \\
(\% \text { of total } \mathrm{Hg})\end{array}$ & $\begin{array}{c}3 \\
\mathrm{H}_{2} \mathrm{O}_{2} \\
(\% \text { of total } \mathrm{Hg})\end{array}$ & $\begin{array}{c}4 \\
\mathrm{H}_{2} \mathrm{O}_{2} \\
(\% \text { of total } \mathrm{Hg})\end{array}$ & $\begin{array}{c}5,6 \\
\mathrm{KMnO}_{4} \\
(\% \text { of total } \mathrm{Hg})\end{array}$ \\
\hline No $\mathrm{Hg}(0) \mathrm{Spi}$ & iking & & & & & & \\
\hline Method 29 & CRG & 7.2 & - & - & - & 97 & 3 \\
\hline $\begin{array}{l}\text { Method 29* } \\
\text { Hg(0) Spikin }\end{array}$ & $\begin{array}{l}\text { CRG } \\
\text { ig }\end{array}$ & 7.5 & 89 & 6 & 2 & 1 & 2 \\
\hline Method 29 & WS Inlet & 18.1 & - & - & - & 67 & 33 \\
\hline Method 29* & WS Inlet & 18.4 & 52 & 15 & 10 & 6 & 17 \\
\hline
\end{tabular}


Table 5

Intratrain Spiking Results Before the First Impinger

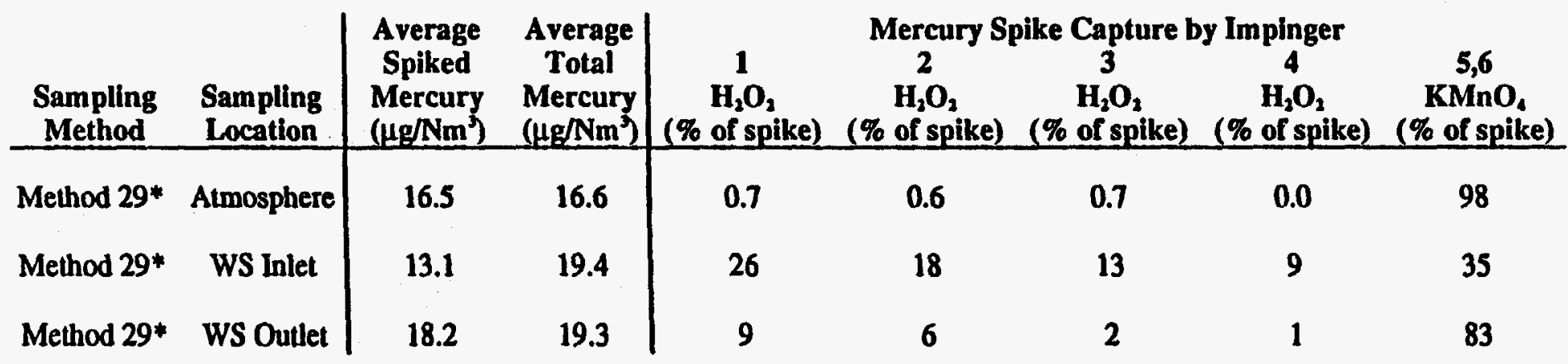


Table 6

Intratrain Spiking Results After the Second Impinger

\begin{tabular}{|c|c|c|c|c|c|c|c|c|}
\hline \multirow[b]{2}{*}{$\begin{array}{c}\text { Sampling } \\
\text { Method }\end{array}$} & \multirow[b]{2}{*}{$\begin{array}{l}\text { Sampling } \\
\text { Location }\end{array}$} & \multirow{2}{*}{$\begin{array}{l}\text { Average } \\
\text { Spiked } \\
\text { Mercury } \\
\left(\mu g / \mathrm{Nm}^{3}\right)\end{array}$} & \multirow{2}{*}{$\begin{array}{l}\text { Average } \\
\text { Total } \\
\text { Mercury } \\
\left(\mu \mathrm{g} / \mathrm{Nm}^{3}\right)\end{array}$} & \multicolumn{5}{|c|}{ Mercury Spike Capture by Impinger } \\
\hline & & & & $\begin{array}{c}1 \\
\mathrm{H}_{2} \mathrm{O}_{2} \\
(\% \text { of spike })\end{array}$ & $\begin{array}{c}2 \\
\mathrm{H}_{2} \mathrm{O}_{2} \\
\text { (\% of spike) }\end{array}$ & $\begin{array}{c}3 \\
\mathrm{H}_{2} \mathrm{O}_{2} \\
(\% \text { of snike) }\end{array}$ & $\begin{array}{c}4 \\
\mathrm{H}_{2} \mathrm{O}_{2} \\
(\%)\end{array}$ & $\begin{array}{c}5,6 \\
\text { KMnO }\end{array}$ \\
\hline Method 29* & WS Inlet & 13.1 & 20.8 & - & - & 24 & 16 & 60 \\
\hline Method 29* & WS Outlet & 17.8 & 19.5 & - & - & 6 & 2 & 92 \\
\hline
\end{tabular}


Table 7

$\underbrace{3}_{\substack{0 \\ \hdashline}}$

Summary of Lime/DBAGypsum Test Conditions and Results

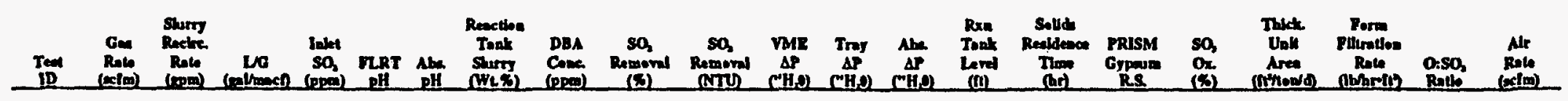

Serouning

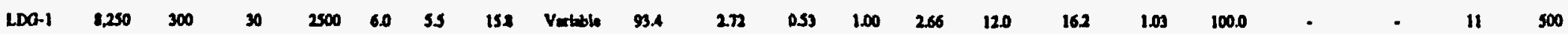

\begin{tabular}{|c|c|c|c|c|c|c|c|c|c|c|c|c|c|c|c|c|c|c|c|c|c|}
\hline \multicolumn{22}{|c|}{ 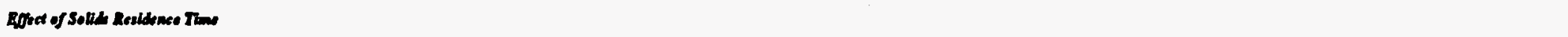 } \\
\hline LDO-2 & 8.250 & 300 & 30 & 2500 & 6.0 & 5.1 & 155 & 2.900 & 905 & 2.35 & 0.57 & 0.99 & 2.94 & 12.0 & 168 & 1.07 & 99.7 & 0.9 & 1150 & 11 & 500 \\
\hline LDO-3 & 8,250 & 300 & 30 & 2500 & 6.0 & 3.2 & 8.1 & $\mathbf{2 8 0 0}$ & 90.6 & 2.37 & 0.61 & 0.98 & 3.30 & 12.0 & 8.0 & 1.05 & 99.8 & 15 & 1409 & $\|$ & 500 \\
\hline LDO-4 & $\$ 250$ & 300 & 30 & 2500 & 6.0 & 5.3 & 4.4 & 3.600 & 90.6 & 2.37 & 0.66 & 0.99 & 3.13 & 12.0 & 3.9 & 1.19 & 100.0 & 1.7 & 42 & II & 300 \\
\hline
\end{tabular}

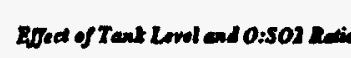

\begin{tabular}{|c|c|c|c|c|c|c|c|c|c|c|c|c|c|c|c|c|c|c|c|c|}
\hline \multirow[t]{2}{*}{ LDO-S } & 8.250 & 300 & 30 & 2000 & 6.0 & 5.1 & 43 & 2.150 & 91.7 & 2.49 & 0.71 & 128 & 3.39 & 12.0 & 48 & 1.08 & 100.0 & 3.4 & $n$ & 14 \\
\hline & 8,250 & 300 & 30 & 2000 & 6.0 & 5.2 & 4.2 & 1.950 & 923 & 2.36 & 0.70 & 1.27 & 3.51 & 8.0 & 3.2 & 1.10 & 99.6 & 3.6 & 305 & 14 \\
\hline LDO-7 & 1.250 & 300 & 30 & 2000 & 6.0 & 53 & 43 & 2.300 & 933 & 2.70 & 0.71 & 151 & 3.78 & 80 & 3.1 & 1.09 & 99.7 & 3.0 & 1172 & II \\
\hline LDO-: & 8.250 & 300 & 30 & 2000 & 6.0 & 5.0 & 41 & 2,450 & 90.7 & 2.38 & 0.60 & 105 & 2.71 & 80 & 3.2 & 121 & 100.0 & 18 & 1732 & 8 \\
\hline
\end{tabular}

\section{Eotect of Residenes Timo}

\begin{tabular}{|c|c|c|c|c|c|c|c|c|c|c|c|c|c|c|c|c|c|c|c|c|}
\hline LDO-9 & 8.250 & 300 & 30 & 2000 & 6.0 & 5.2 & 42 & 2,450 & 92.4 & 2.58 & 0.62 & 1.13 & 2.74 & 8.0 & 143 & 1.19 & 99.9 & 2.2 & 1464 & 6 \\
\hline LDO-10 & 8.250 & 300 & 30 & 2000 & 65 & 5.3 & 43 & 29000 & 923 & 2.56 & 0.61 & 120 & 279 & 8.0 & 32 & 1.25 & - & • & • & 6 \\
\hline & 11,000 & 425 & 33 & 20000 & 6.5 & 5.4 & 140 & 1,850 & 923 & 256 & 1.02 & 187 & 4.60 & 8.0 & 82 & 1.08 & & & 1283 & 10 \\
\hline
\end{tabular}

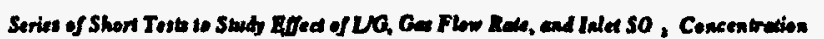

\begin{tabular}{|c|c|c|c|c|c|c|c|c|c|c|c|c|c|c|c|c|c|c|c|c|c|}
\hline LDO-11A & 8.250 & 300 & 30 & 2000 & 6.0 & 52 & 10.1 & 2000 & 87.7 & 2.09 & 0.63 & 1.17 & 2.77 & 8.0 & 53 & . & - & . & . & 16 & 350 \\
\hline LDa-11B & 8.250 & 300 & 30 & 2000 & 6.0 & 4.9 & 8.2 & - & 90.6 & 236 & 0.63 & 1.16 & 2.83 & 80 & 38 & - & - & - & - & 6 & 217 \\
\hline LDO-1IC & 1250 & 300 & 30 & 2000 & 6.0 & 5.0 & 71 & 2,450 & 90.7 & 2.31 & 0.63 & 1.17 & 280 & 8.0 & ss & - & . & . & - & 8 & 290 \\
\hline 100.110 & 1.250 & 300 & 30 & 2700 & 6.1 & 5.0 & 8.0 & 2,750 & 92.1 & 2.53 & 0.63 & 1.17 & 288 & 8.0 & 4.2 & 1.14 & 98.9 & 1.8 & 1495 & 6 & 290 \\
\hline LDO-1IB & 8.250 & 400 & 40 & 2000 & 60 & 4.9 & 78 & . & 95.7 & 3.14 & 0.63 & 1.25 & 3.03 & 8.0 & 53 & . & . & • & • & 6 & 217 \\
\hline LDO-IIP & 11,000 & 400 & 30 & 2000 & 6.0 & 4.9 & 10.3 & 2,200 & 892 & 229 & 107 & 184 & 4.75 & 8.0 & 6.0 & 1.00 & 92.9 & 35 & 440 & 6 & 290 \\
\hline
\end{tabular}


Table 7

Summary of LimedDBA Gypsum Test Conditlons and Results

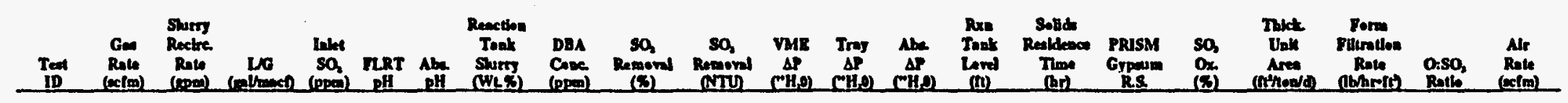

\begin{tabular}{|c|c|c|c|c|c|c|c|c|c|c|c|c|c|c|c|c|c|c|c|c|c|}
\hline \multicolumn{22}{|c|}{ 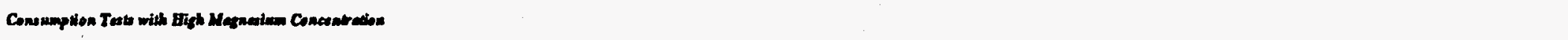 } \\
\hline LDG.12 & 8,250 & 300 & 30 & 2000 & 6.5 & s8 & 116 & 3.150 & 92.7 & 2.61 & 0.61 & 1.10 & 3.06 & 12.0 & 13.0 & 1.01 & 100.0 & 0.7 & 6653 & 6 & 217 \\
\hline TI & 8,250 & 300 & 30 & 2000 & 6.0 & 5s & 7.2 & 2,800 & 92.4 & 258 & 0.58 & 1.18 & 3.03 & 8.0 & 5.7 & 1.09 & 995 & 42 & 2620 & 8 & 291 \\
\hline $\mathbf{T}$ & 8,250 & 300 & 30 & 2000 & 5.9 & s.5 & 12.2 & 2,800 & 925 & 259 & 0.5: & 1.14 & 3.12 & 80 & 10.0 & 1.10 & 99.7 & 2.0 & 2510 & 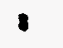 & 291 \\
\hline \multicolumn{22}{|c|}{ 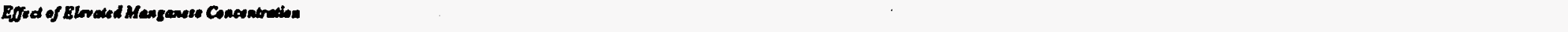 } \\
\hline $\mathbf{T}$ & 11,000 & 400 & 30 & 2500 & 53 & 52 & 12.6 & 2550 & 98 & 2.29 & 0.93 & 1.93 & 5.25 & 10 & 6.2 & 1.26 & 282 & 23 & 2557 & 9 & 552 \\
\hline \multicolumn{22}{|c|}{ Refred of Solid Wro and Residenec Time } \\
\hline T4 & 11,000 & 400 & 30 & 2000 & 53 & s.o & 263 & 2,450 & 69.9 & 2.30 & 0.18 & 1.72 & 3.94 & 8.0 & 175 & 1.16 & 99.1 & 82 & 1.3 & 1557 & 12 \\
\hline TS & 11,000 & 400 & 30 & 2000 & ss & 4.7 & 305 & 2,475 & 295 & 226 & 0.18 & 1.83 & 3.98 & 8.0 & $21 s$ & 1.11 & 99.6 & 75 & 2.2 & 2934 & 12 \\
\hline \multicolumn{22}{|c|}{ Etod of tremix Tank } \\
\hline TS & 11,000 & 400 & 30 & 2000 & 35 & 4.7 & 27.5 & 2,475 & 29.5 & 2.26 & 0.18 & 183 & 3.90 & 2.0 & 218 & 1.11 & 99.6 & 75 & 2.2 & 2934 & 12 \\
\hline T6 & 11,000 & 400 & 30 & 2000 & ss & 5.0 & 31.4 & 2,900 & 891 & 2.31 & 0.18 & 1.93 & 424 & 8.0 & 21.8 & 1.15 & 99.8 & 80 & 1.3 & 2841 & 12 \\
\hline
\end{tabular}




\section{APPENDIX A}

\section{TEST SCHEDULES}




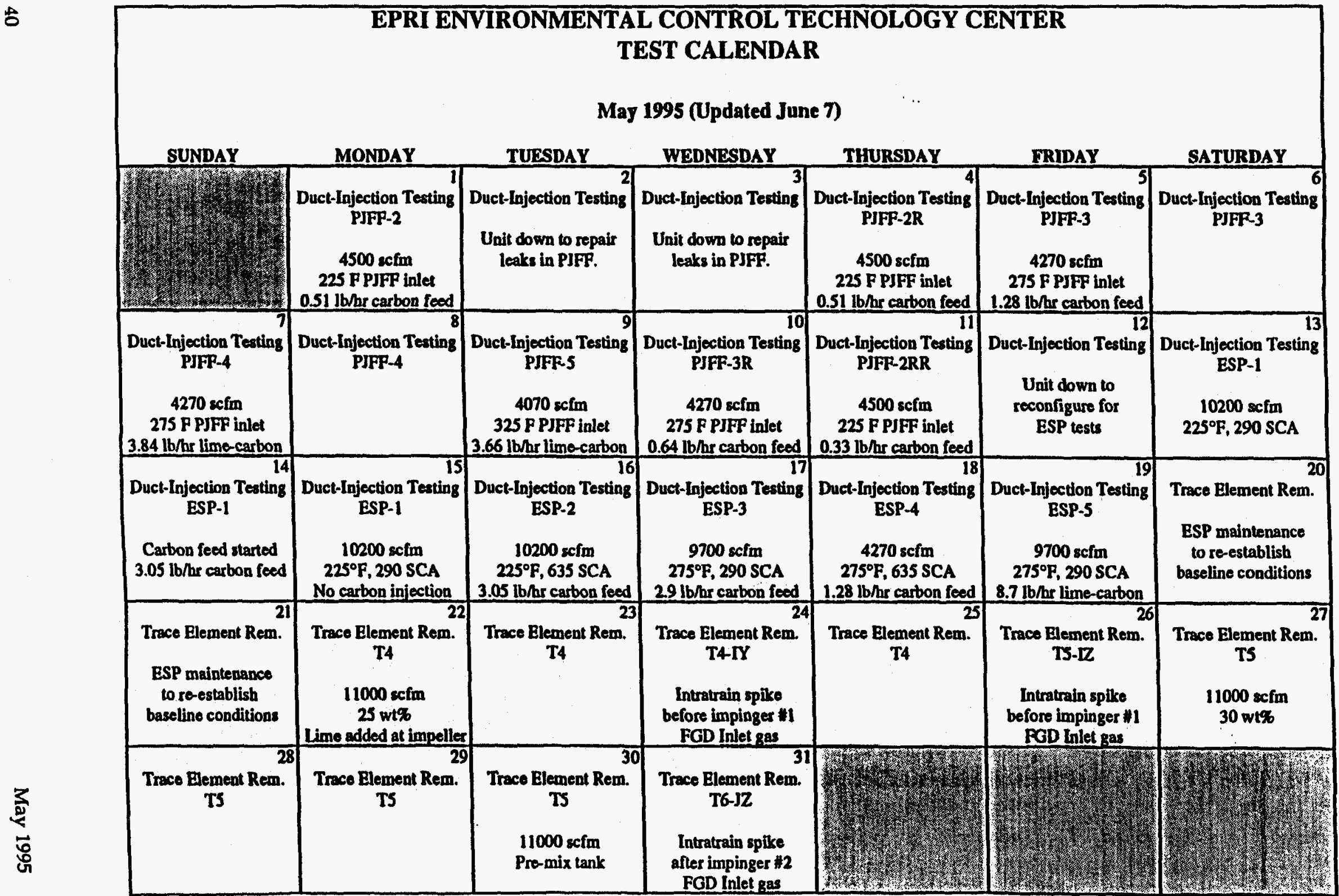




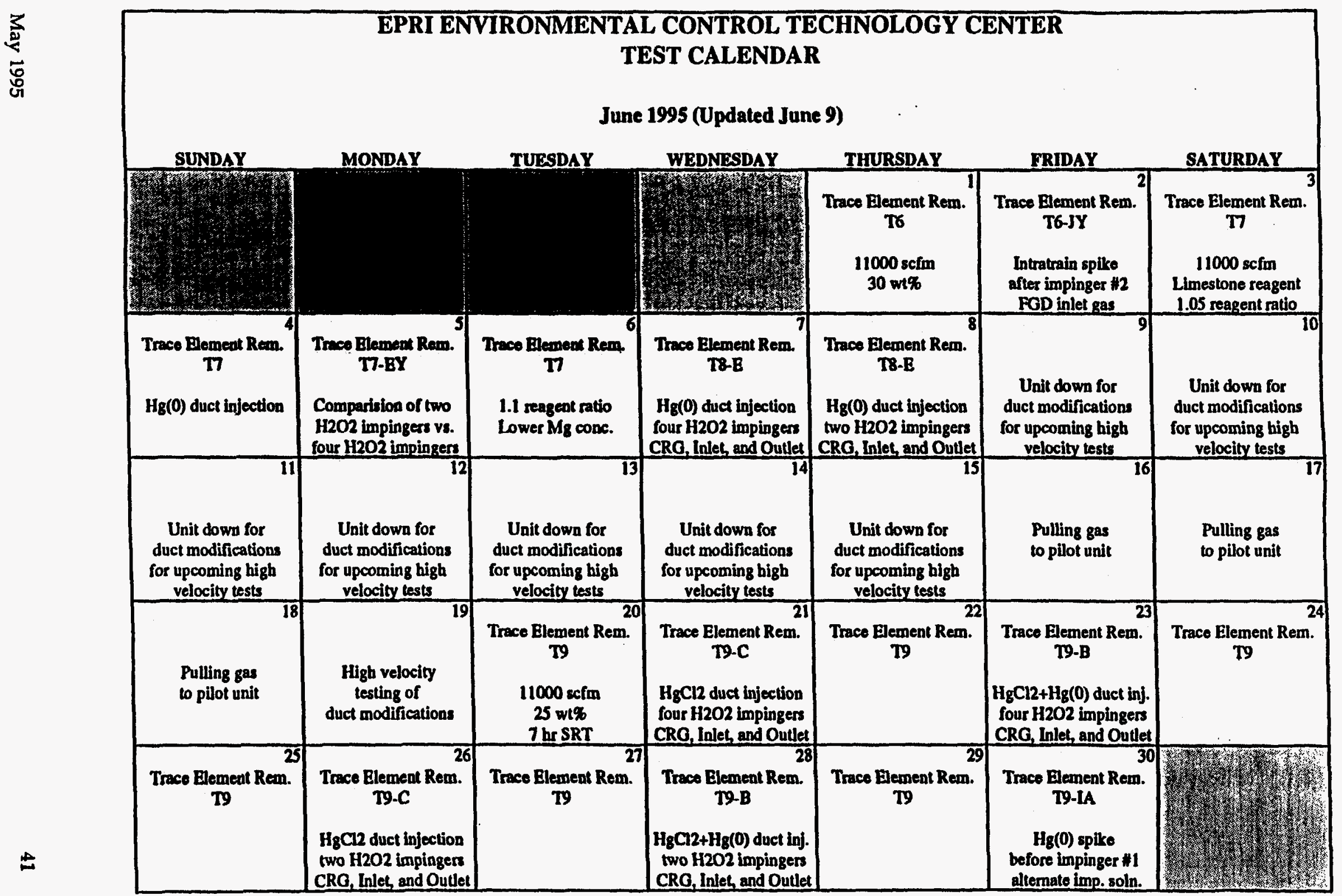


APPENDIX B

PILOT AND MINI-PILOT DATA 
T4 Process Summary Report

(5/2495 16:00:00 to 5/26195 11:00:00)

\begin{tabular}{|c|c|c|c|c|c|}
\hline Process Variable & Averise & Max & $\mathrm{Mm}$ & Sid.Dex. & Points \\
\hline SO2 Rewornl (9) & 89.9 & 91.7 & 88.1 & 0.7 & 43 \\
\hline SO2 Removal (NIU) & 230 & 249 & 213 & 0.07 & 43 \\
\hline La Ratio (gel/man) & 30 & 31 & 30 & 0 & 43 \\
\hline Renction Tanis ofI & 5.50 & 5.51 & 5.39 & $\mathbf{0 . 0 2}$ & 43 \\
\hline Absater pll & 5.02 & 5.11 & 4.90 & 0.06 & 43 \\
\hline Rue Ges Flow Rets (sefin) & 11001 & 11047 & 10998 & 7 & 43 \\
\hline Header 1 Flow (spm) & 400 & 400 & 400 & $\mathbf{0}$ & 43 \\
\hline Header 3 Flow (rpan) & $\mathbf{0}$ & $\mathbf{0}$ & $\mathbf{0}$ & $\mathbf{0}$ & 43 \\
\hline Header 5 Flow (apd) & $\mathbf{0}$ & 0 & 0 & $\mathbf{0}$ & 43 \\
\hline Blowdown so Sunp Raie (spm) & $\mathbf{0 . 1 1}$ & 0.18 & 0.00 & 0.09 & 43 \\
\hline Centrifuge Feed Rite (apm) & 3.16 & 420 & 268 & 0.47 & 43 \\
\hline Rengen Feed eo FLRT (epm) & 1.79 & 200 & 1.58 & 0.16 & 43 \\
\hline Faciticy Inlet SO2 Cona (ppm) & 1199 & 1365 & $\boldsymbol{T 7 2}$ & 136 & 43 \\
\hline Inlet SO2 Concemention (ppm) & 2000 & 2015 & 1986 & 6 & 43 \\
\hline Ortet SO2 Concentrition (ppm) & 189 & 223 & 156 & 14 & 43 \\
\hline Inlet 02 Concentration (9) & 8.98 & 1276 & 7.48 & 1.22 & 43 \\
\hline Oulat 02 Concantration (\%) & 8.64 & 11.89 & 7.38 & 1.02 & 43 \\
\hline Aboctber Gas Velocity (tisec) & 11.18 & 11.23 & 11.13 & 0.02 & 43 \\
\hline Inlet Gas Tempecanve (P) & 318 & 326 & 316 & 2 & 43 \\
\hline Onlat Gen Tenperine (P) & 124 & 126 & 120 & 1 & 43 \\
\hline SO2 Abotred (mnoled) & 1564 & 16.08 & 1527 & 0.14 & 43 \\
\hline Salids Reridence Time (br) & 17.5 & 17.9 & 17.0 & 0.2 & 43 \\
\hline Sluxy Reridence Time (min) & 952 & 9.52 & 9.51 & 0.00 & 43 \\
\hline Abcorber Presalre Drop (in H2O) & 3.94 & 3.96 & 3.90 & 0.01 & 43 \\
\hline Spay Zone Prentre Drop (in H2O) & 1.98 & 2.04 & 1.83 & 0.05 & 43 \\
\hline Trny Preare Drop (in 120 ) & 1.72 & 1.78 & 1.57 & 0.05 & 43 \\
\hline ME Presune Drop (in H2O) & 0.18 & 0.19 & 0.18 & 0.00 & 43 \\
\hline Oxidution Air to Rrn Tank (acfm) & 550 & 550 & 550 & $\mathbf{0}$ & 43 \\
\hline DBA Addition Rate (mL/min) & 0 & 0 & 0 & $\mathbf{0}$ & 43 \\
\hline NYSEG Lond (MW) & 521 & 684 & 178 & 128 & 43 \\
\hline
\end{tabular}

T5 Procen Summary Report

(5/28/95 13.00100 to 5/30195 0800200)

\begin{tabular}{|c|c|c|c|c|c|}
\hline Proces Variable & Averige & Mex & Mln & StdDer. & Polnts \\
\hline SO2 Removil (\$) & 89.5 & 902 & 88.9 & 0.4 & 19 \\
\hline SO2 Removal (NTU) & 2.26 & 2.32 & 2.20 & 0.04 & 19 \\
\hline LA Ratio (gal/mach) & 31 & 32 & 31 & $\mathbf{0}$ & 19 \\
\hline Renation Tank pH & 5.50 & 5.50 & 5.49 & 0.00 & 19 \\
\hline Abeorber pH & 4.74 & 4.90 & 4.63 & 0.08 & 19 \\
\hline Five Gas Flow Rate (sefm) & 10991 & 11071 & 10745 & 60 & 19 \\
\hline Header 1 Flow (epm) & 400 & 400 & 400 & $\mathbf{0}$ & 19 \\
\hline Header 3 Flow (apm) & 0 & $\mathbf{0}$ & 0 & $\mathbf{0}$ & 19 \\
\hline Header 5 Flow (opa) & 0 & o & 0 & $\mathbf{0}$ & 19 \\
\hline Blowdowa to Sump Rale (spm) & 0.21 & 0.21 & 0.21 & 0.00 & 19 \\
\hline Centrifuge Feed Rete (opm) & 228 & 263 & 1.75 & 0.26 & 19 \\
\hline Rengent Feod to FLRT (pin) & 1.70 & 1.73 & 1.67 & 0.02 & 19 \\
\hline Fucility Inlet SO2 Conc (ppm) & 1418 & 1565 & 1304 & 74 & 19 \\
\hline Inla SO2 Concentretion (ppm) & 2000 & 2009 & 1992 & 4 & 19 \\
\hline Oullet SO2 Conocontration (ppm) & 196 & 207 & 183 & 7 & 19 \\
\hline Inles 02 Coscantration (\$) & 8.73 & 9.51 & 7.64 & 0.51 & 19 \\
\hline Outlet O2 Consentration (\%) & 8.41 & 9.00 & 7.53 & 0.40 & 19 \\
\hline Absocher Gas Velocity (It/ece) & 10.98 & 11.08 & 1065 & 0.10 & 19 \\
\hline Inlet Gas Temperatiso (F) & 327 & 335 & 317 & 4 & 19 \\
\hline Oriliat Ger Temperature (F) & 126 & 127 & 125 & 1 & 19 \\
\hline SO2 Abecabed (mmolen) & 1557 & 15.70 & 15.33 & 0.08 & 19 \\
\hline Solido Residence Time (hes) & 21.8 & 222 & 21.6 & 0.1 & 19 \\
\hline Sluny Rexidenco Time (min) & 9.51 & 9.52 & 9.51 & 0.00 & 19 \\
\hline Aboorber Preanure Drop (in H2O) & 3.98 & 4.00 & 3.93 & 0.02 & 19 \\
\hline Spray Zane Presarre Drop (in H2O) & 208 & 2.15 & 1.57 & 0.13 & 19 \\
\hline Tray Prescure Drop (in Hi2O) & 1.83 & 1.90 & 1.31 & 0.13 & 19 \\
\hline ME Preararo Drop (in H2O) & 0.18 & 0.18 & 0.18 & 0.00 & 19 \\
\hline Oxidation Air to Ren Tank (eafin) & 550 & 551 & 549 & 0 & 19 \\
\hline DBA Addition Rate (mL/min) & 0 & 0 & 0 & $\mathbf{0}$ & 19 \\
\hline NYSEG Laad (MW) & 573 & 680 & 460 & 83 & 19 \\
\hline
\end{tabular}


T6 Process Summary Report

(601/95 08:00:00 6o 6/02/95 08:00:00)

\begin{tabular}{|c|c|c|c|c|c|}
\hline Process Variable & Average & Max & $\mathrm{Min}$ & Std.Der. & Points \\
\hline SO2 Removal (\$) & 89.8 & 92.8 & 805 & 2.8 & 24 \\
\hline SO2 Removal (NTU) & 2.31 & 2.63 & 1.63 & 0.23 & 24 \\
\hline LG Ratio (gal/mach) & 30 & 30 & 30 & 0 & 24 \\
\hline Renction Trnk pH & 5.30 & 5.82 & 4.50 & 0.32 & 24 \\
\hline Abectber pH & 4.77 & 5.08 & 4.56 & 0.13 & 24 \\
\hline Fluo Gas Flow Rate (scfm) & 11000 & 11003 & 10997 & 2 & 24 \\
\hline Header 1 Flow (gpm) & 400 & 400 & 400 & $\mathbf{0}$ & 24 \\
\hline Header 3 Flow (gpm) & o & $\mathbf{0}$ & $\mathbf{0}$ & $\mathbf{0}$ & 24 \\
\hline Header 5 Flow (spm) & 0 & 0 & 0 & 0 & 24 \\
\hline Blowdown to Sump Rate (gpm) & 0.27 & 0.27 & 0.27 & 0.00 & 24 \\
\hline Centrifuge Feed Rate (spm) & 6.60 & 7.55 & 1.79 & 1.17 & 24 \\
\hline Reagent Feed to FLRT (spm) & 1.65 & 1.87 & 1.24 & 0.15 & 24 \\
\hline Facility Inlet SO2 Conc (pm) & 1419 & 1590 & 1085 & 157 & 24 \\
\hline Inlet SO2 Concentration (ppm) & 1999 & 2013 & 1987 & 6 & 24 \\
\hline Outlet SO2 Concentration (pPm) & 192 & 367 & 136 & 52 & 24 \\
\hline Inlet $\mathrm{O} 2$ Concentration (\$) & 7.58 & 8.24 & 7.09 & 0.26 & 24 \\
\hline Outlat O2 Concentration (\%) & 7.44 & 8.07 & 7.09 & 0.24 & 24 \\
\hline Abeorber Gas Velocity (fisec) & 11.23 & 11.40 & 11.17 & 0.06 & 24 \\
\hline Inlet Gas Temperature (F) & 320 & 349 & 313 & 10 & 24 \\
\hline Outlet Gas Temperature (F) & 126 & 129 & 124 & 1 & 24 \\
\hline SO2 Abeorbed (mmolen) & 15.62 & 16.26 & 13.99 & 0.49 & 24 \\
\hline Solids Reridence Trme (hro) & 21.8 & 24.3 & 209 & 0.7 & 24 \\
\hline Slurry Reaidence Timo (min) & 9.52 & 9.52 & 9.51 & 0.00 & 24 \\
\hline Abeorber Presenre Drop (in H2O) & 4.24 & 4.29 & 4.20 & 0.03 & 24 \\
\hline Spray Zone Presenure Diop (in H2O) & 2.19 & 2.25 & 2.14 & 0.03 & 24 \\
\hline Tray Precerure Drop (in H2O) & 1.93 & 1.98 & 1.88 & 0.03 & 24 \\
\hline ME Presure Drop (in H2O) & 0.18 & 0.19 & 0.18 & 0.00 & 24 \\
\hline Oxidation Air to Rxn Tank (acfm) & 550 & 551 & 548 & 1 & 24 \\
\hline DBA Addition Rate (mL/min) & 0 & 0 & 0 & $\mathbf{0}$ & 24 \\
\hline NYSEG Load (MW) & 678 & 695 & 644 & 13 & 24 \\
\hline
\end{tabular}




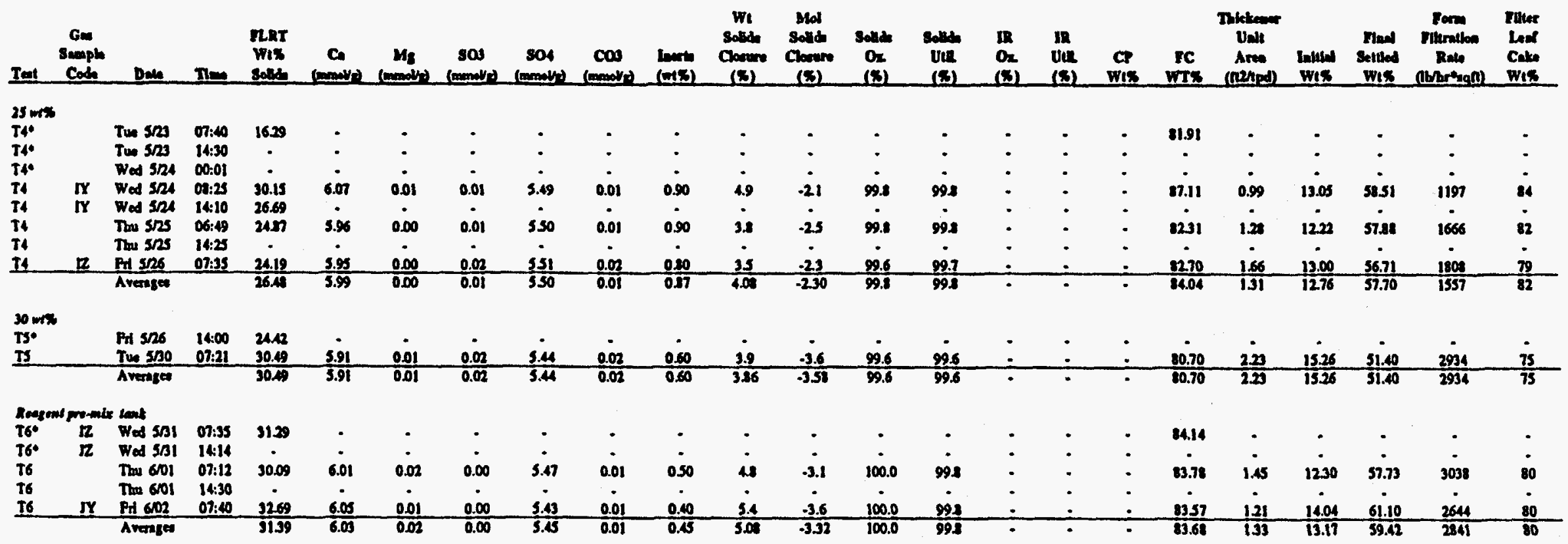




\begin{tabular}{|c|c|c|c|c|c|c|c|c|c|c|c|c|c|c|c|c|c|c|c|c|c|c|c|}
\hline & 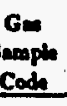 & Den & $\pi=$ & $\begin{array}{c}\text { MRT } \\
\text { pRt }\end{array}$ & ARS & $\begin{array}{l}\text { LCCot+ } \\
\text { (mMM) }\end{array}$ & $\begin{array}{c}\operatorname{LMg}_{(\mathrm{M}++} \\
\end{array}$ & L & $\begin{array}{c}2 x_{t} \\
\text { (pppe) }\end{array}$ & 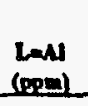 & $\begin{array}{l}\text { LFe } \\
\text { (ppea) }\end{array}$ & $\underset{\text { (ppos) }}{\operatorname{Lrm}}$ & $\underset{c o M}{\log }$ & $\begin{array}{l}\text { Lcas } \\
\text { (IM) }\end{array}$ & $\begin{array}{c}\text { LsO3- } \\
\text { (mMD) }\end{array}$ & $\begin{array}{l}\text { LSO4 } \\
\text { (aMM }\end{array}$ & $\begin{array}{c}\text { ICR } \\
\text { DRA } \\
\text { (pRpel }\end{array}$ & $\begin{array}{l}\text { ICE } \\
\text { Adipk } \\
\text { (aid }\end{array}$ & $\begin{array}{l}\text { ICE } \\
\text { Gluturk } \\
\text { (IMM) }\end{array}$ & $\begin{array}{c}\text { ICE } \\
\text { Sucetok } \\
\text { (mM) }\end{array}$ & $\begin{array}{c}\text { Cossos } \\
\text { RS }\end{array}$ & $\begin{array}{c}\text { CusO4 } \\
\text { RS }\end{array}$ & $\begin{array}{c}\mathrm{CACOS} \\
\mathrm{RS} \\
\end{array}$ \\
\hline & & & & & & & & & & & & & & & & & & & & & & & \\
\hline & & Tue 3/2 & 07:40 & 5.61 & . & 18.9 & 659.22 & 13.47 & • & - & - & 53.00 & - & - & 424 & • & 4499 & 20.66 & 1.97 & 3.29 & - & - & $\cdot$ \\
\hline T40 & & Tue $5 / 23$ & $14: 30$ & 350 & 4.96 & • & & & & - & $\bullet$ & & & & . & - & $\cdot$ & • & & & & . & \\
\hline $14^{\circ}$ & & Wed $5 / 24$ & $\infty 0: 01$ & & & & & • & & . & 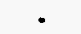 & & 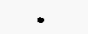 & & & 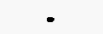 & 272 & 14.40 & 2.87 & 2.46 & . & . & 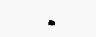 \\
\hline T4 & $\boldsymbol{x}$ & Wed $5 / 24$ & 0:25 & 3.12 & 412 & 18.90 & 465.30 & 11.22 & 100.40 & 4.42 & 0.00 & 39.26 & 352.91 & 0.80 & 6.22 & 274.11 & 1871 & 9.24 & 1.96 & 2.21 & 0.76 & 1.22 & 0.00 \\
\hline I4 & & Dod $5 / 2 \Omega$ & $06: 49$ & $\begin{array}{l}352 \\
352\end{array}$ & s.oe & ing & $42 n$ & 11.00 & issso & 50.79 & 0.00 & 37.09 & 3726 & 0.82 & 6.49 & 270.6 & 294 & 16.92 & 189 & $2 \dot{2 x}$ & 0.90 & 1.16 & 0.00 \\
\hline I4 & & Thu 5/25 & $14: 25$ & 5.49 & & . & & & & & & & & & & & & & & & & & \\
\hline & z & Pri 5128 & & 9.46 & 4.90 & 19.15 & 45.23 & 10.96 & 109.00 & $4.3 !$ & 0.00 & 34.4 & 304.61 & 0.66 & 4.01 & 241.02 & 2460 & 13.82 & 1.58 & 1.98 & 0.54 & 1.11 & 0.00 \\
\hline & & Avernge & & 5.16 & 498 & 19.00 & 464.12 & 11.09 & 110.97 & 4724 & 0.00 & 37.14 & 313.40 & 0.76 & 357 & 261.94 & 2438 & 13.33 & 1.82 & 2.14 & 0.73 & 1.16 & 0.00 \\
\hline $30 \mathrm{mt}$ & & & & & & & & & & & & & & & & & & & & & & & \\
\hline TS" & & Fri $5 / 26$ & $14: 00$ & 5.52 & & & & & & $\therefore$ & $\therefore$ & & & & & $\cdot$ & & & & & & $\cdot$ & \\
\hline Is & & Tue sno & $09: 21$ & 532 & 490 & B...8 & s.52.50 & 1202 & 1200 & 49.49 & 0.02 & 5422 & 237.92 & 0.78 & 1184 & 249.12 & 2475 & $13.6 !$ & $0 . x$ & 3.26 & 1.67 & 2.11 & 0.00 \\
\hline & & Averases & & 352 & 4.90 & 18.8 & 45450 & 1202 & 12280 & 49.49 & 0.02 & 54.22 & 287.99 & 0.75 & 1184 & 249.12 & 2475 & 13.61 & 0.78 & 3.26 & 1.67 & 1.11 & 0.00 \\
\hline & & & & & & & & & & & & & & & & & & & & & & & \\
\hline $\begin{array}{l}T 6^{\circ} \\
76^{\circ}\end{array}$ & $\begin{array}{l}\mathbf{1 2} \\
\mathbf{z}\end{array}$ & $\begin{array}{l}\text { Wed } 5 / 31 \\
\text { Hed } S B 1\end{array}$ & $\begin{array}{l}07: 35 \\
14: 14\end{array}$ & $\begin{array}{l}536 \\
530\end{array}$ & 4.84 & 19.69 & 472.91 & 1217 & & - & : & : & $\cdot$ & - & 453 & & 2894 & 16.05 & 0.80 & 3.7 & - & - & - \\
\hline T6 & & Thu 601 & 07:12 & 5.79 & 5.00 & 19.90 & 459.55 & 31.16 & 135.50 & 35.95 & 0.00 & 57.20 & 284.69 & 0.79 & 4.26 & 250.15 & 2754 & 14.91 & 184 & 283 & 0.90 & 8.17 & 0.01 \\
\hline & $\boldsymbol{X}$ & $\begin{array}{l}\text { Thu } 601 \\
\operatorname{Pot} 602\end{array}$ & $\begin{array}{l}14: 30 \\
07: 40\end{array}$ & $\begin{array}{l}5.41 \\
5.90\end{array}$ & & 19.12 & 477.64 & 13 & iiso & & 000 & & 316 & 0.70 & 832 & 258.08 & 3059 & 16.89 & 180 & 301 & & & \\
\hline & & $\frac{m_{1}}{\text { Averagla }}$ & & $\frac{350}{357}$ & $\frac{4.7}{4.9}$ & $\frac{19.12}{19.51}$ & $\frac{917.64}{168.60}$ & 1150 & $\frac{14.10}{139.80}$ & 49.99 & $\frac{.003}{0.02}$ & $\frac{30.00}{57.03}$ & $\frac{300.10}{300.42}$ & $\frac{0.10}{0.75}$ & $\frac{132}{6.29}$ & $\frac{258,05}{25.27}$ & $\frac{309}{2906.20}$ & $\frac{10.89}{15.90}$ & $\frac{180}{182}$ & $\frac{3.01}{292}$ & $\frac{1.13}{1.02}$ & $\frac{1.12}{1.15}$ & $\frac{0.00}{0.01}$ \\
\hline
\end{tabular}




\section{ECTC COSPONSORS DISTRIBUTION}

Ms. Debra DiMeo (10)

Empire State Electric Energy Res. Corp. 1515 Broadway

New York, NY 10036

Ph. (212) 302-1212

Fax: (212) 302-1377

Mr. John E. Smigelski (10)

New York State Electric \& Gas

Corporate Drive, Kirkwood Ind. Park

P. O. Box.5224

Binghamton, NY 13902-5224

Ph: (607) 762-8688

Fax: (607) 762-8457

Dr. Gerald Janik

New York State Electric \& Gas

Corporate Drive, Kirkwood Ind. Park

P. O. Box 5224

Binghamton, NY 13902-5224

Ph: (607) 762-4318

Fax: (607) 762-8457

Mr. Takayuki Ogawa

Electric Power Development Co., Ltd

6-15-1, Ginza, Chuo-ku

Tokyo 104 JAPAN

Ph: (81) 3-3546-9404

Fax: (81) 3-3546-9482
Mr. Michael Perlsweig

U.S. Department of Energy

FE-22/GTN

Washington, DC 20545

Ph: (202) 353-4399

Fax: (202) 353-4399

Ms. Joanne Zysk (7)

U.S. Department of Energy

Pittsburgh Energy Technology Center P. O. Box 10940, MS 900-33

Pittsburgh, PA 15236

$\mathrm{Ph}$ : (412) 892-6200

Fax: (412) 892-6216

Mr. Jonas S. Klingspor

ABB Environmental Systems

31 Inverness Center Parkway

Birmingham, AL 35243

Ph: (205) 995-5360

Fax: (205) 995-5364

\section{EPRI DISTRIBUTION}
G. Andes
R. Glover
R. Moser
G. Preston
W. Chow
M. Miller
G. Offen 